\title{
The People of the Pen: Self-Perceptions of Status and Role in the Administration of Empires and Polities
}

\author{
Maaike van Berkel
}

\section{Introduction}

\begin{abstract}
May God protect you who practise the craft of writing, and may he guard you, help you, and give you guidance. God has divided mankind, after the prophets and messengers - may God bless them and keep them safeand after the honoured kings, into ranks, even if they are in reality equal. God put at their disposal different kinds of crafts and various sorts of businesses, so that they might be able to make a living and earn their sustenance. He placed you, o scribes (kuttab), in the most honoured position of the men of good education and virtues, of knowledge and composure. By your efforts the good things of the caliphate become well organized and its affairs are set right. Through your advice, God puts a suitable government over the people and the land prospers. The ruler cannot dispense with you. You alone make him a competent ruler. Your position with regard to rulers is that you are the ears through which they hear, the eyes through which they see, the tongues through which they speak, and the hands through which they feel. May God give you, therefore, enjoyment of the excellent craft with which he has distinguished you, and may he not deprive you of the great favours that he has shown you. ${ }^{1}$
\end{abstract}

These words are the opening lines of a treatise (Risala ila al-Kuttab) written in the first half of the eighth century by an official of the central administration of the Umayyad caliphate in Damascus, 'Abd al-Hamid b. Yahya (d. $\left.75^{\circ}\right) .^{2}$ In

1 'Abd al-Hamid b. Yahya, 'Risala ila l-kuttab', in: Muhammad Kurd 'Ali, ed., Rasa'il al-bulagha (Cairo, 1913, 2nd edition) 172.

2 Wadad al-Qadi, 'Early Islamic State Letters. The Question of Authenticity', in: Averil Cameron and Lawrence I. Conrad, eds., The Byzantine and Early Islamic Near East (Princeton, 1992) I, 215-275. Idem, "Abd al-Hamid al-Katib', in: Michael Cooperson and Shawkat M. Toorawa, eds., Dictionary of Literary Biography, vol. 311, Arabic literary culture, 500-925 (Detroit, 2005) 3-11. 
his epistle 'Abd al-Hamid addresses his fellow scribes and prescribes their education and skills, their character of modesty, trustworthiness, and integrity, and the way in which they should relate to superiors, inferiors, and fellow scribes.

Grafted onto older, mainly Sassanian, traditions, 'Abd al-Hamid's risala set the standard for almost all later descriptions of the people of the pen in the Islamic world. It was copied in the works of famous authors of the Mamluk era, such as Ibn Khaldun (d. 1406) and al-Qalqashandi (d. 1418), and the Ottoman era-even as late as the eighteenth century-, such as Ahmed Resmi Efendi (d. 1783). ${ }^{3}$ In his Sefinet Ahmed Resmi acknowledged the continuing value of this epistle, a millennium after it was written, by declaring:

I have added here as a conclusion and appendix the work of 'Abd alHamid b. Sa'id ${ }^{4}$ which is generally reckoned among the famous books of knowledge and worthy of attention and emulation. ${ }^{5}$

The risala's fame even travelled beyond the boundaries of the Ottoman world; it also influenced the Safavid and the Mughal advice literature of the sixteenth and seventeenth centuries. ${ }^{6}$

This example demonstrates the long-term and entangled scribal traditions of the Islamic worlds of West and South Asia. This chapter will make an even broader comparison, between the various worlds represented in our project, the 'Sinosphere', Christian Europe, and the Islamic worlds of West and South Asia, and it will focus on the period 1300-16oo, a period of striking bureaucratic developments in all three regions. State officials who staffed the central administrations of the pre-modern Eurasian polities will take centre stage. Together with the people of the sword, the people of the pen constituted important intermediaries between the ruler and his subjects. Each in their own way, pen and sword were instrumental in the keeping together of polities; they were the ruler's two pillars. The people of the pen grew from the royal households to form a group of their own. They formed the elites of their polities, profiting

3 See, Virginia H. Aksan, An Ottoman Statesman in War and Peace:Ahmed Resmi Efendi (Leiden, 1995) 4-5.

4 'Abd al-Hamid b. Sa'id is the same as 'Abd al-Hamid b. Yahya whose full name is 'Abd al-Hamid b. Yahya b. Sacid [or Sacid] al-Katib.

5 Translation in Aksan, An Ottoman Statesman, 5.

6 See, for example, a letter written by Chandrabhan 'Brahman' to his son Khvajah Tej Bhan. Muzaffar Alam and Sanjay Subrahmanyam, 'The Making of a Munshi', Comparative Studies of South Asia, Africa and the Middle East 24, no. 2 (2004) 61-72. 
from the distribution of the riches and political influence at the centre and, in their turn, protecting and propagating the dynasty among its subjects and disseminating writing and written culture in administration.

This important position as one of the main pillars of their polities makes the people of the pen a central group in our project. Their relevance becomes even more evident when we realize that many of the historical sources we use today to understand the functioning of Eurasian polities were written by these people. The officials of the Chinese, European, West and South Asian central administrations not only used their writing skills for the production of official charters, diplomatic letters, and financial accounts, they also brought forth an extensive corpus of miscellaneous texts, including chronicles, political advice literature, books on etiquette, poetry, and geographical surveys. It is often through their eyes that we get to know the politics, institutions, daily practices, intellectual debates, and moral codes of the societies in which they lived. Their perceptions, perspectives, and analyses define our general views on past empires and polities. The study of their literature entails an awareness of the ways in which we perceive the workings of theses polities.

This chapter will make the perspective of the state officials the object of analysis by critically interpreting their self-perceptions on their role in the keeping together of empires. With its focus on self-identifications it links up with Gommans' analysis of the other pillar of power, the people of the sword. How did the officials envision the role of the pen in the integration of empires and polities? How did they see their task in the imperial project? How did they describe their relationships with others such as the people of the sword or the ruler? What aspects of the official's craft and ethos did they indicate as crucial for good governance? Variations within and between Eurasian traditions will be analysed in the context of the power constellations of the various polities in their various stages, thus elucidating the role of the people of the pen and their related self-perceptions during these developments. Due to the cultural embeddedness of these self-perceptions, the parallels and contingencies between the various regions will inform us about variety in mechanisms as well as more universal developments of officialdom within the diverse polities.

For the sake of comparison, I will use the term state official within this chapter. The term is alien to the traditions studied in this volume. As we argued in the general introduction of the book, the use of conceptual terminology in a comparative study comes with certain risks. When alien concepts are applied to a society, there is always the possibility of distorting the historical categories as used by contemporaries and therefore misinterpreting their experience. At the same time, the variety in conceptual terminology, used by the authors of 
our sources, could stand in the way of comparisons between various traditions. The term state official refers here to all those people entrusted with the administrative tasks of their polity—whether epistolary, financial, or legaland using the pen to fulfil these tasks. Throughout this section other terms such as people of the pen, scribes, magistrates, and administrators, or contemporary terminology such as the Chinese shi, the Arabic katib, or the Mughal munshi will be used. A precise demarcation of this group as a whole is impossible in this comparative approach.

All Eurasian polities that are part of our comparative project developed at some point an administrative structure with institutions that were complex enough to enable the emergence of a (more or less confident) professional class of state officials dealing with administrative-chancery, financial, and judicial—matters. However, these developments were far from linear, parallel, or uniform throughout Eurasia and throughout time. Many differences existed in the tasks, status, and functioning of state officials. Those at the top of the hierarchical ladder will be the focal point of my analysis. We are not only best informed about these top officials, but they are generally also the ones who produced and advertised the professional ethos of the group as a whole and determined the way we look at empires and polities.

Self-images of the group were formulated in a wide variety of sources from poetry to chronicles. In order to make a source-based comparative analysis possible and meaningful, I will rely on works that can be grouped under the generic term of advice (or mirror) literature. Advice literature, works of instruction for rulers and members of the political elite, was produced in all these areas throughout time. We should, however, keep in mind that advice literature is a multifaceted genre that is difficult to circumscribe. State officials formulated their views on good governance in texts that vary in style, content, and length. They appear in the form of short letters, but also in encyclopaedic administrative manuals of several volumes. Moreover, they are often difficult to discern from historical works as the latter also incorporate prescriptive elements, historical examples meant to elucidate good and bad governance. In this chapter I will focus on advice texts written by and for officials of the polities and empires of Eurasia in which the officials formulate their self-images and provide instructions for their fellow scribes.

Analysing the officials' self-presentations in a comparative study with a wide scope and including so many diverse traditions has a few advantages. Firstly, officials of all polities studied in this project brought forth works of advice on good governance, and they have specified their own role within the ideal models they laid down. In general, much of the information on the administrative practices we have for the earlier periods of our project is in fact normative. 
Therefore, analysing the ideals, the norms, of the officials makes a comparative approach much more feasible than comparing practical outlines of the administrations on an equal basis. By working with a limited number of (advice) texts that contain a set of corresponding characteristics, comparisons can be made between the self-definitions of penmen between and within the different traditions. Having said that, we should, however, keep in mind that not only the (functional) characteristics of their self-presentations, but also the various styles (for example, epistolary excellence) and genres (historiographies, model books, works of rhetoric, lists of indispensable books) they used to express these characteristics define their views and proclaimed role and status in society. Throughout these comparisons, the political and social developments in which the self-images developed will be taken into account.

Secondly, analysing the voices from within, comparing the ideal self-representations and referring to the categories and concepts used in the advice texts themselves, might help to avoid the - frequently criticized, but unfortunately still often applied-use of ethnocentric (generally Eurocentric) categories of interpretation for societies and systems that fit uneasily into these models. Obviously, analysing self-perceptions and distinguishing contemporary and source-restricted categories will be useful only if we keep in mind that we are comparing ideal categories and specific perspectives, and not (necessarily) actual practices, although these ideals are embedded in and emerge from everyday practice.

The chronological focal point in this chapter will be the years between 1300 and 16oo. These three centuries witnessed a series of profound, though different, administrative developments in all three worlds. In East Asia, the Mongol Yuan had introduced their own clientele and replaced some of the earlier Chinese scribal traditions, while at the same time building on the previous Tang and Song divisions of the administration. Under their successors, the Ming dynasty, the famous Chinese civil examinations became the decisive recruitment mechanism for officials on all levels. A dual administration similar to that practised under the Yuan in China became customary in parts of the Islamic world with the rise of the Mongols. Other parts of West Asia, the Mamluk sultanate for example, built on the previous Arabic scribal traditions. Centralization and bureaucratization characterized the rapidly growing Ottoman Empire, and in South Asia the Persian-writing scribe emerged. European polities were certainly not at the vanguard of administrative developments at the beginning of this period, but a group of new scribes did appear in many polities of late medieval Europe. The decision to focus on this specific period means that the expanding administrations in European polities and the emergence of influential and self-assured new groups of high state officials and ministers in Europe 
from the late sixteenth century onwards will largely fall outside the scope of this study. Obviously, this demarcation is for practical reasons and not meant to deny that these later developments changed Europe from the relative latecomer in my analysis into a forerunner of bureaucratic practices and ideals in the centuries to come. Since similar developments of a scribal class, and certainly of professional awareness, are lacking in the Russian Empire before 16oo, Russia will not be a part of this analysis.

Three regional clusters constitute the geographical framework of this analysis: the Chinese, Islamic, and European worlds. In each of these clusters internal developments and regional differentiations are discernible. Administrative procedures, but also normative descriptions of secretaries were appropriated, adjusted, developed, and intertwined with other traditions throughout time and from region to region according to local prerequisites and expectations. Comparisons between the three clusters will demonstrate different types of secretarial self-presentation in the imperial project. Connected traditions between the clusters - when apparent - will also be analysed.

The political and social processes that led to the emergence and development of professional officialdom within the three regions will be discussed in the first part of this chapter on the basis of studies which do not (yet) provide a comprehensive view. The historiography on pre-modern administrative systems is uneven. Compared to the Chinese and Islamic worlds, Europe's bureaucratic traditions have received a lot of attention, especially the regional and national developments of the administrations. On the other hand, the professional ethos of the literati has been explored in much more detail for the various periods in Chinese history and, to a lesser extent, for the Islamic world.

The second part of this chapter will focus on the sources and the officials' self-perceptions within them. It starts with a short overview of the genres in which self-perceptions of officials appeared. Subsequently, it analyses how these penmen defined their own expertise and contribution to the administration of their polities: their general cultural capital, their expert (judicial, financial, or epistolary) knowledge, and, finally, their professional ethos. The chapter concludes with an analysis of the ways in which officials saw their own position vis-à-vis other groups in society, more specifically, the rulers they served and the scribes' seemingly most important antagonists, the people of the sword. 
Among the 'four people' it is the shi who bear the responsibility for Heaven, Earth, men and things. Even if they live in remote huts, their concern is always for the whole realm and for posterity. ${ }^{7}$

According to fourteenth-century Confucian thought-here in the words of Wei $\mathrm{Su}$ (d. 1372), one of the most prominent Southern Chinese literati under the Yuan - the shi (generally translated in English as literati or scholar-officials or gentlemen) constituted one of the four categories of people, each of which represented an occupational group within a normative social hierarchy. The place of each group within the hierarchy was based upon the value of this group for society's well-being. The shi were at the top, followed by the farmers, the artisans, and the merchants. If all groups would properly perform their assigned duties, order and harmony would prevail. Wei Su's statement, like many other references to these four (or sometimes six) categories of occupations, clearly demonstrates the professional awareness of this group within the Chinese territories.

At the beginning of the era under consideration in this book, around the year 1300, not all Eurasian polities had state officials who displayed a clear and distinct professional ethos. Self-awareness among officials can be linked to the size of the administrative apparatuses these polities employed, but also to the scribal and intellectual traditions of the region to which they belonged and the social structures within these polities. The three main regions of our project follow their own trajectories in this respect. The years $1300-1600$ form a particular moment in a much longer history. Chinese men of the pen proclaim a strongly self-conscious identity in written texts from the period of the Warring States (453-221 BCE). ${ }^{8}$ In the Islamic world communal awareness among the officials of the central administration was visible from the eighth century, when the first advice works by and for this professional class appear. In most European polities such a consciously proclaimed professional identity—distinguishable from other identities - came relatively late, in the later Middle Ages, and was during the whole of the period 1300-160o less precisely defined and detailed than in East and West Asia.

7 Translation in John Dardess, Confucianism and Autocracy. Professional Elites in the Founding of the Ming Dynasty (Berkeley, Los Angeles, and London, 1983) 82.

8 See on shi thoughts during the Warring States, Yuri Pines, Envisioning Eternal Empire: Chinese Political Thought of the Warring States Era (Honolulu, 2009). 
The chronological discrepancies between the three main traditions of this analysis have resulted in an unequal representation of their scribal traditions and professional ethos for the pre-1300 era. There is more to say about group consciousness among the Chinese pre-13oo state officials than there is for their European counterparts. Since Europe and, to a lesser extent, West and South Asia, were politically more fragmented than China, less attention can be paid to developments in each and every polity within these fragmented areas. Nevertheless, all sections will pay attention to the factors causing the emergence of a self-aware group of officials, their recruitment, and the traditions on which they built.

\subsection{Imperial China}

For a period of almost two and a half millennia the people of the pen played a crucial role in Chinese cultural and political history. Obviously, neither the composition of this group nor its self-image remained constant throughout these centuries. Some of the earlier major developments will be discussed here before moving to the period 1300-16oo, when the Mongol Yuan and the Ming dynasties ruled the Chinese territories.

The development of the position of the people of the pen in the Chinese territories from the Warring States $\left(453^{-221} \mathrm{BCE}\right)$ onwards is generally explained in conjunction with a long transition of the ruling elite from predominantly aristocratic to predominantly meritocratic. ${ }^{9}$ An important step in this development was the establishment of an examination system for officials under Han emperor $\mathrm{Wu}$ (r. 141-87 BCE). During the Han era, this system was still very rudimentary, and it took another millennium, until the period of the Northern Song (96o-1127) before it developed into a more mature system. However, the impact of the examination system on Chinese history is immense as it would influence recruitment of officials for centuries to come. It is also during the Han dynasty, in the first century вСЕ that Confucianism triumphed as official ideology and came to dominate court policy. One of the most conspicuously new elements of this ideology was that, according to Confucius, someone's status depended on his moral qualities and not his pedigree. A 'superior man' was in Confucianism no longer a high-ranking noble, but a self-made learned and morally upright man who was proud of his modest background. ${ }^{10}$ Despite the de facto elitist background of many of people of the pen then and in later eras, this ideal of and its Imperial Legacy (Princeton, 2012) 78; Pines, Envisioning, 115-186. 
educational and moral superiority as decisive for one's status remained predominant in their self-images throughout the centuries. ${ }^{11}$

From late Han times on officials were categorized with some variation according to the Nine Ranks system, which contained nine numbered ranks each divided into two classes, upper and lower. Also posts within the administration were numbered in that way. So when an $8 \mathrm{a}$ (upper class- 8 rank) post became vacant, it was generally, but not consistently, filled by an official of that rank or someone who was ready for promotion to that rank. Salaries corresponded with ranks, although special allowances were often added to the official salary.

These Nine Ranks officials did not form the majority of the civil service. Large numbers of unranked, subordinate specialists performed the daily executive administrative tasks of the administration such as drafting and record keeping. ${ }^{2}$ They were also categorized and paid according to a graded system, and some of them were promoted to the ranks of superior officials. ${ }^{13}$ The selfrepresentations discussed in this chapter emanate, however, mainly from the top layers of the administration, the officials or magistrates. The subordinate specialists - clerks and runners - were viewed with disdain by the ranked officials and belonged to a completely different social and cultural category. They receive much less attention in the sources. On the other hand, the culture and ideology of the high officials was shared by a group of people who did pass or sat the exams but were not employed as officials. These poets, painters, calligraphers, teachers, or former officials were part of the same networks as the literati officials. ${ }^{14}$

Also since Han times extensive rules, 'avoidances', were designed to prevent or minimize corruption among officials. Officials were not allowed to serve in their native districts, while lesser functionaries, the non-official specialists,

11 Mark Edward Lewis, Writing and Authority in Early China (Albany, 1999) 218, 351. See also Jacques Gernet, 'Le réforme confucéenne', in: Jacques Gernet, L'intelligence de la Chine: Le social et le mental (Paris, 1994) 8-87; Hartman, 'Sung Government', 32; Pines, Everlasting Empire, 90-91.

12 For an estimation of the numbers of officials see, Jeroen Duindam, 'The Court as a Meeting Point', chapter 2 in this volume.

13 For an overview of the various administrative institutions and the detailed hierarchy of its personnel, see Charles O. Hucker, A Dictionary of Official Titles in Imperial China (reprint; Beijing, 2008); idem, 'Governmental Organization of the Ming Dynasty', Harvard Journal of Asiatic Studies 21 (1958) 1-66; idem, 'Ming Government', in: Denis C. Twitchett and Frederick W. Mote, eds., The Cambridge History of China: Volume 8, The Ming Dynasty, (Cambridge, 1998) 9-105.

14 See, for example, Craig Clunas, Art in China (New York, 2009). 
generally were. This prevented officials from staffing their offices with their own clients and family members. Similarly, kinsmen were prohibited from serving in the same agency as their relatives. ${ }^{15}$

The examinations were potentially a mechanism for the emperor to impose a specific vision upon the (future) elites of his administration. However, in practice long-term modifications in the examinations proved generally impossible without the consent of the literati themselves; indeed, they often instigated changes in the curriculum. ${ }^{16}$ The negotiations between various stakeholders can be followed in the developments of the curriculum and subject matter of the examination system under the Song dynasty. ${ }^{17}$ This curriculum became eventually dominated by neo-Confucianism (The Learning of the True Way, Daoxue). This development was far from a top-down achievement, but as much a process of dissemination from below, particularly through private academies. After generations of literati who sympathized with the neo-Confucian curriculum, in the thirteenth and fourteenth centuries their interpretations of the canonical works triumphed and became incorporated into the examination system under the late-Yuan and early-Ming emperors. ${ }^{18}$

The Song dynasty is also the era during which the examination system expanded and became one of the main gateways to a career in the state administration. Although the system functioned earlier, it was under the Song that much larger percentages of officials actually went through the system and that families without a history of office-holding were recruited for government service through the examinations. ${ }^{19}$ The examination system thus functioned as mechanism for social mobility.

15 Hucker, Dictionary of Official Titles, 5.

16 Benjamin Elman, A Cultural History of Civil Examinations in Late Imperial China (Berkeley, 2000).

17 Hilde De Weerdt, Competition over Content: Negotiating Standards for the Civil Service Examinations in Imperial China (1127-1279) (Cambridge, MA and London, 2007) 16.

18 Peter Bol, 'Examinations and Orthodoxies: 1070 and 1313 Compared', in: Theodore Huters, R. Bin Wong and Pauline Yu, eds., Culture and State in Chinese History (Stanford, 1997) 2957; Peter Bol, Neo-Confucianism in History (Cambridge, 2008); James T. Liu, 'How did a NeoConfucian School Become the State-Orthodoxy?', Philosophy East and West 23, no. 4 (1973) 483-505; De Weerdt, Competition over Content. See also Hilde De Weerdt, Reinventing Chinese Political History (Inaugural Lecture, Leiden, 2014).

19 Hartman, 'Sung Government', 34 and 54. See also Thomas H.C. Lee, Government Education and Examinations in Sung China (New York, 1985). Hilde De Weerdt provides numbers for the early and late Song and sees an important increase in numbers between these two periods, De Weerdt, Reinventing, 5 . 
At the same time, it is important to note that still a large proportion of the officials under the Song dynasty — but also under later dynasties— took different paths to officialdom. Statistics for the Song refer to probably fifty per cent that got lower positions through the yin or 'protection' privilege, which comprised granting to officials the right to directly appoint designated brothers, sons, and grandsons and sometimes even unrelated persons to office. ${ }^{20}$ Others entered through other systems such as transfers from the army or purchasing office. $^{21}$

Initially, the Mongol Yuan dynasty (r. 1264-1368) did not show specific interest in controlling education for official appointments and recruitment through examinations was abolished. Internal promotions based on regular evaluations remained, however, intact. The basic structure of the Yuan administration, which was already established under its founder Kublai Khan (r. 126o-1294), saw quite a few innovations in the system, while at the same time continuing a mixture of Jurchen Jin, Chinese Tang, and Song elements. The Yuan kept intact, for example, the traditional Chinese division into civil (the Secretariat), military (the Bureau of Military Affairs), and censorial offices (the Censorate), but, in line with their own traditions, in everyday administration, they gave a much larger role to the military. ${ }^{22}$ They continued to use a centralized and well-organized formal administrative system of agencies similar to their predecessors, but real authority did not seem to be with the officeholders responsible for certain tasks within this system, but with Mongol overseers (darughachi) who often remained behind the scenes. ${ }^{23}$

The Mongols classified the population of Yuan China into four categories, indicating their relevance for governmental service: Mongols; miscellaneous aliens, mostly Central Asian Muslim allies; Northern Chinese residents; Southerners. The most important governmental posts were entrusted to Mongols and Central Asian allies. ${ }^{24}$ The Southern Chinese served only in local offices in their

20 Hartman, 'Sung Government', 55. See also Peter Bol, 'The Sung Examination System and the Shih', Asia Major, Series 3, vol. 3, part 2 (1990) 149-171.

21 Hartman, 'Sung Government', 54 and 58.

22 Elizabeth Endicott-West, 'The Yüan government and society', in: Herbert Franke and Denis Twitchett, eds., The Cambridge History of China. Volume 6. Alien Regimes and Border States, 907-1368 (Cambridge, 1994) 587-615.

23 On the darughachi, see also Jos Gommans, chapter 4 in this volume.

24 John D. Langlois, Jr., 'Introduction', in: John D. Langlois, ed., China under Mongol Rule (Princeton, 1981) 11-13; Morris Rossabi, 'The Muslims in the Early Yüan Dynasty', in: John D. Langlois, ed., China under Mongol Rule (Princeton, 1981) 257-295. 
own areas. ${ }^{25}$ After the initial years the Mongols continued to use the nine ranks from 1 a to $9 \mathrm{~b}$. Within these official ranks officials were further classified through all kinds of prestige titles. The subordinate runners and clerks, specialists in certain administrative areas, took care of the daily routine.

While Mongols dominated the crucial positions, the Yuan recruited the personnel for their administration also from among their Central Asian trusted allies and the Chinese. These latter were often recruited on the basis of traditional Chinese procedures with the exception of the examination system. Officials and subordinate specialists were selected by recommendations from incumbent officeholders and through the 'protection privilege', the appointment of sons and other family members. ${ }^{26}$ Schools were opened to train, first, sons and family members of officials, but subsequently also newcomers. The overseers, generally Mongols who belonged to the military elite, also often occupied hereditary positions. ${ }^{27}$ Many of the officials under the Yuan lacked an examination degree and profound knowledge of the classical Chinese learning. They were known for their legal professionalism but not for their neoConfucian knowledge. ${ }^{28}$ In addition, also some of the Han literati, who enjoyed relative cultural autonomy in private academies and continued to cultivate a self-awareness as an elite group in this era, continued to staff the governmental offices under the early Yuan, but they were not dominant. ${ }^{29}$ Many Han literati developed alternative careers, in, for example, medicine and art. A selfcontained civil officialdom did continue to exist among these groups under the Yuan dynasty.

In search for legitimacy among the Han population and encouraged by their Han and Jurchen officials, the later Yuan rulers reintroduced the examination system in $1313 .{ }^{30}$ Local officials examined candidates every third year, of which the best were sent to provincial examinations. A small number of provincial candidates were then admitted to the metropolitan examinations in which only one out of three was allowed to pass. The Mongol rulers kept an eye on the balance between Han, Mongol, and other non-Han candidates taking part

\footnotetext{
25 Hucker, Dictionary of Official Titles, 66-67.

26 Hucker, Dictionary of Official Titles, 68.

27 Hucker, Dictionary of Official Titles, 59.

28 Elizabeth Endicott-West, Mongolian Rule in China (Harvard, 1989).

29 Elman, Cultural History, 29-30; John Dardess, 'The Cheng Communal Family: Social Organization and Neo-Confucianism in Yuan and Early Ming China', Harvard Journal of Asiatic Studies 34 (1974) 7-53; Langlois, 'Introduction'.

30 John Dardess, Conquerors and Confucians. Aspects of Political Change in Late Yüan China (New York and London, 1973) 35-74.
} 
in the exams, and the contents of the exams differed for the various ethnic groups ${ }^{31}$ With the reintroduction of the examination system under the later Yuan rulers, neo-Confucian thought regained prominence.

Finally, under the Ming dynasty (1368-1644), the civil examinations with a neo-Confucian curriculum became the decisive recruitment mechanism and moulded the empire-wide ideas of officials. The first Ming emperor Zhu Yuanzhang (r. 1368-1398) ordered the establishment of schools for the education, examination, and recruitment of officials for governmental service on all levels. The grand competition took place every three years through provincial, metropolitan, and palace examinations. ${ }^{32}$ Once employed, officials were rated every three years by their superiors in evaluation procedures generally resulting in reassignment.

Traditionally, the Chinese civil examination system has often been described as a predominantly meritocratic system allowing for substantial social mobility. More recent historians have qualified this principle by emphasizing the social and cultural reproduction mechanisms underlying the system. ${ }^{33}$ Although candidates were tested on their knowledge of the classical texts biennially and triennially in local, prefectural, provincial, and palace examinations, the years of study needed to pass these exams, especially at the highest levels, and the necessary financial resources to do so buttressed existing social structures. This also explains why hardly any sons of peasants or artisans participated in exams, certainly not at the metropolitan level. ${ }^{34}$ The examination system did, however, become the main process through which the Ming recruited their officials, and with it Chinese officialdom became less patrimonial and more meritocratic than in any of the earlier periods.

Despite some important developments in social status, political influence, and intellectual training, what is striking is that the literati kept throughout two millennia of Chinese imperial history a strong self-awareness with an

31 Elman, Cultural History, 33-34; Hucker, Dictionary of Official Titles, 69.

32 Hucker, 'Governmental Organization', 81.

33 Elman, Cultural History, xxix-xxxi, xxxvii-xxxviii and 239-294. See also Benjamin Elman, 'Social, Political and Cultural Reproduction via Civil Service Examinations in Late Imperial China', The Journal of Asian Studies 5o, no. 1 (1991) 7-28. See Elman, Cultural History, xxxvii-xxxviii, nt. 4, for his reply to the criticism of his argument.

34 Others have criticized Elman's analysis as giving too much emphasis to the enhancement of the status quo and the dynastic hegemony over the system. See, for example, Kai-wing Chow, 'Writing for Success. Printing, Examinations and Intellectual Change in Late Ming China', Late Imperial China 17, no. 1 (1996) 122. De Weerdt, Competition, 15-16. See Elman's reaction to this criticism, Elman, Cultural History, xix and xxxviii. 
elitist view on their role in society as moral guides not only of the common people, but also the rulers. Culturally and intellectually they remained certainly dominant throughout the Song-Yuan-Ming era. Politically they competed with the emperor himself, his relatives, the eunuchs, and the people of the sword. ${ }^{35}$ While $w u$ (the sword) could be more prominent in periods of regime change and crisis, most of the time the pen seems to have occupied the culturally dominant position.

\subsection{The Islamic World}

For West, Central, and South Asia this paragraph will analyse the connected, but also constantly changing, scribal traditions of the Islamic world stretching from the Abbasids to the Mamluks and Ottomans in the West, via the Ilkhanids, Timurids, and Safavids in Persia to the Mughals of South Asia. The non-Islamic regimes of this region will not be discussed here, although I realize that in some cases, especially in India, the non-Islamic scribal traditions influenced those of the Islamic polities. This does not mean that non-Muslim scribes will be outside the scope of this analysis. On the contrary, a conspicuous number of the officials of the Islamic regimes were non-Muslims.

As mentioned in the introduction, the treatise by 'Abd al-Hamid b. Yahya is one of the first expressions of the professional and cultural ethos of this tradition that have come down to us. During the latter years of his life 'Abd alHamid was head of the chancery of the Umayyad caliphate (661-750). However, it was not until the Abbasids (eighth-tenth centuries) that we find frequent and more elaborate self-expressions of this tradition in a wide variety of advisory texts. This increase was related to two more general developments in the course of the ninth and tenth centuries.

Firstly, the Abbasids expanded their administrative apparatus and with it the number of secretaries working in it. Unfortunately, we cannot reconstruct exact figures, but the number of special bureaus, their subdivisions, and assigned tasks as described in the administrative literature suggests the presence of substantial numbers of scribes in the central apparatus by the end of the ninth century. These scribes received monthly salaries that varied according to their rank. Generally, only the heads of the various bureaus are known to us by name. Many of them came from secretarial families whose members had staffed the administration for some time. With the expansion of the administrative apparatus in the course of the ninth century, the Abbasids started 
to recruit their secretarial staff from the land-holding elites in Iraq. Religious minorities, especially Shiites and Christians, were well represented among them. ${ }^{36}$

Secondly, this era saw some major steps in the extension and spread of literacy. Some recent studies have emphasized how the growth of book production and the development of a culture that valued writing highly were related to the introduction of paper in Iraq in the late eighth century. ${ }^{37}$ Like so many other Arabic genres, advisory texts for and by scribes (in Arabic often but not consistently referred to as adab al-katib) also reached a peak in the course of the late ninth and early tenth centuries. The authors of these texts were inspired by Persian advice texts and scribal traditions. The Abbasid texts are the main sources for an analysis of the officials' expressions of self-awareness in this era, and they were an inspiration for officials in the eras to come.

The Abbasid caliphs recruited their financial and epistolary officials generally from specific families and their clients. Also the entry level and professional success of officials were highly dependent upon systems of patronage and family networks. These officials received on-the-job training. Judicial officials took a slightly different path. While in the Umayyad period the office of qadi was a kind of legal secretary, similar to his financial and epistolary colleagues, under the Abbasids the judiciary started to develop a certain independence from the ruler. Under influence of the increasing status of religious and legal scholars ('ulama') and the rise of transregional law schools, qadis resisted political interference with the judiciary and developed discourses on judicial autonomy. ${ }^{38}$

The Abbasid administrative and scribal traditions would continue to set standards for many administrations in later centuries, despite sometimes far-

36 On the background, administrative specializations, and salaries, see Maaike van Berkel, Nadia El Cheikh, Hugh Kennedy, and Letizia Osti, Crisis and Continuity at the 'Abbāsid Court. Formal and Informal Politics in the Caliphate of al-Muqtadir (295-320/908-932) (Leiden, 2013) especially chapter 4; Maaike van Berkel, 'Archives and Chanceries: pre-1500, in Arabic', in: K. Fleet, et al., eds., Encyclopaedia of Islam Three (Leiden, 2013) 24-32; Paul L. Heck, The Construction of Knowledge in Islamic Civilization. Qudāma b. Jaffar and his Kitāb al-kharāj wa-șinā'at al-kitāba (Leiden, 2002).

37 See, for example, Jonathan Bloom, Paper before Print. The History and Impact of Paper in the Islamic World (New Haven, CT, 2001); Shawkat Toorawa, Ibn Abi Tahir Tayfur and Arabic Writerly Culture: A Ninth Century Bookman in Baghdad (London, 2005). See also Maaike van Berkel, 'Communication and Contention. The Role of Literacy in Conflict with 'Abbāsid Officials', History Compass 5, no. 5 (2007) 1661-1676.

38 Mathieu Tillier, 'Judicial Authority and Qādīs' Autonomy under the 'Abbāsids', Al-Masāq 26, no. 2 (2014) 119-131; Idem, Les cadis d'Iraq et l'État Abbasside (132/750-334/945) (Damascus, 2009). 
reaching changes in the political arena after the disintegration of the Abbasid caliphate in the middle of the tenth century. In the Eastern part of the former caliphate, for example, Daylamites from the Southern Caspian shores took over large parts of Iran and Iraq including the Abbasid capital Baghdad. They brought forth the next ruling dynasty of this era, the Shicite Buyids. ${ }^{39}$ They broke up the old and elaborate system of direct tax collection and payment of salaries and used the land-grant system (iqtac) instead. As a consequence, the size of the central administrative apparatus shrank drastically. Also the background of the staff changed. While some of clerks low in the hierarchy were still from Baghdad's hinterland, the new viziers and high officials were generally of Persian background. ${ }^{40}$ The Buyid period was an era of great economic distress, but, at the same time, courtly culture flourished, and for that reason the era has also been labelled the 'Renaissance of Islam.41 In their quest for legitimization the Buyid emirs became patrons of literature, learning, and the translation of Greek and Persian texts into Arabic. Scribes were among the principal bearers of this culture, not only producing books of political and administrative advice, but also philosophical texts, poetry, and chronicles. ${ }^{42}$

In 1055, a new political constellation emerged when the Turkish Seljuks led by Tughril Bey conquered Iran, Iraq, Syria, and Anatolia. Their (travelling) court consisted mostly of military commanders. Most officials frequented the court, but did not travel with it and remained in one of the administrative centres. The administrative divisions remained intact with a chancery, a financial bureau, and a bureau for the treasury, but — due to the continuity of the iqta' system and the independent activities of local Seljuk leaders who were unwilling to submit to central rule-these were rather rudimentary. ${ }^{43}$ Viziers and secretaries continued to be mainly of non-Turkish, Persian, and Arab descent, and the Seljuks turned to them for advice on administrative practices and political thought. One of them, the vizier Nizam al-Mulk, wrote one of the best known

39 On the Buyids, also called Buwayhids, see John J. Donohue, The Buwayhid Dynasty in Iraq 334H./945 to 403H./1012. Shaping Institutions for the Future (Leiden and Boston, 2003).

40 Donohue, Buwayhid Dynasty, 162.

41 See, for example, Adam Mez, Die Renaissance des Islams (Beirut, 1973; reprint 1922) and Joel L. Kraemer, Humanism in the Renaissance of Islam. The Cultural Revival During the Buyid Age (Leiden, 1993, revised edition of 1986).

42 Kraemer, Humanism, 208-209.

43 Ann K.S. Lambton, Continuity and Change in Medieval Persia (Albany, 1988) 11 and 297-309; Ann K.S. Lambton, Landlord and Peasant in Persia (Oxford, 1953; 1991 Reprint of revised version of 1969) $53^{-76}$. 
political advice books of the era. ${ }^{44}$ In general, the Persian scribal traditions continued to flourish also in the Eastern dynasties of Iran, among the Samanids, Ghaznavids, and Ghurids. With the collapse of the Seljuk rule in the course of the twelfth century and the emergence of the regimes of their vassals, the Khwarazm dynasty in Samarqand, the Rum Seljuks in Anatolia, and the Ayyubids in the Levant and Egypt and the re-emergence of the Abbasids in Baghdad, similar administrative traditions continued to be used. ${ }^{45}$

In the middle of the thirteenth century the Mongols swept away the Khwarazm shahs, the Seljuks of Anatolia, and the Abbasid caliphs in Baghdad, while the Ayyubids in Egypt and Syria were succeeded by their former slave soldiers, mamluks, who came from the Turkic areas in Central Asia. The Mamluk sultans built on the long-standing traditions of Egyptian administrative practices, although they added a series of military officials in charge of the civil officials. ${ }^{46}$ The Mongols, in their turn, introduced a composite administrative system, maintaining practices of the Steppe and adding Chinese and Persian elements.

Unlike the situation under the Seljuk Turks, who had been tribal but Muslim and who, also due to their smaller numbers, had adapted smoothly to the administrative and political order in Iran, the Mongol conquest led to fundamental transformations in the administrative structure. The Central Secretariat created by Möngke (r. 1251-1259), Chinggis Khan's third successor, had a regional branch in Iran, in Khorasan, headed by a Mongol governor, who was assisted by representatives of the Great Khan (darughachi) and members of the Chinggisid families, but with local administrators, who came from the traditional secretarial families who had often also served the Seljuks and the Khwarazm shahs. ${ }^{47}$ Under Möngke's brother Hülegü, Iran became an ulus, a

44 Nizam al-Mulk, The Book of Government or Rules for Kings. The Siyar al-muluk or Siyasatnama of Nizam al-Mulk, trans. Hubert Drake (London and New York, 2002).

45 See, for example, Linda Darling, A History of Social Justice and Political Power in the Middle East. The Circle of Justice from Mesopotamia to Globalization (London and New York, 2013) 85-102; A.C.S. Peacock and Sara Nur Yildiz, eds., The Seljuqs of Anatolia. Court and Society in the Medieval Middle East (London, 2013).

46 Bernadette Martel-Thoumian, Les civils et l'administration dans l'état militaire Mamlūk (IXe/Xve siècle) (Damascus, 1991) 35-76.

47 Denise Aigle, 'Iran under Mongol Domination: The Effectiveness and Failings of a Dual Administrative System', Bulletin d'Études Orientales, Supplément 57 (2008) 65-78; Thomas T. Allsen, Mongol Imperialism. The Policies of the Grand Qan Möngke in China, Russia and the Islamic Lands (Berkley, 1987); Lambton, Continuity and Change, 297-309. 
tributary state ruled by the Ilkhanids (1258-1336). The darughachi, generally Mongols or Asian Turks, controlled the local administrators, collected taxes and tributes, and were responsible for the population census. They had troops at their disposal. In other words, a kind of dual administration came into being, one Mongol or non-indigenous, the other Iranian. The Ilkhan's court, ordo, was where recruitment for important administrative positions took place. Here the great emirs lived with the ruler and here Persian elite families could plead their case by becoming clients of a Mongol emir. ${ }^{48}$ The dual system of the Mongols continued to function under the Timurids with two diwans (administrative bureaus), one dealing with taxes and correspondence and staffed by Persians, the other dealing with military affairs and staffed by Turco-Mongolians. ${ }^{49}$

Unlike the Mongols, the Mamluks immediately adopted the extensive administrative apparatus that had functioned under their predecessors, the Ayyubids and the Fatimids, which in its turn, was largely based on Abbasid practices. This is visible in the organization of the various bureaus, the archival practices, and the epistolary style of the chancery documents. ${ }^{50}$ Many scribes still came from specific secretarial families, among whom Christians and Jews were well represented, but also newcomers from Egyptian or Syrian local families who had gained an education at the madrasa were able to make a career in the administration..$^{51} \mathrm{~A}$ tripartite elite, consisting of bureaucrats, jurists-scholars, and religious functionaries, had become apparent. They shared common training and common values, but developed clear professional specialization at the same time. While bureaucrats and jurists were recruited from the major cities of the sultanate, religious functionaries in the capital came from the immediate

48 For more details on the actual functioning of this dual administrations, see, Aigle, 'Iran under Mongol Domination'.

49 Beatrice Forbes Manz, Power, Politics and Religion in Timurid Iran (Cambridge, 2007) 79110; Hans Robert Roemer, Staatsschreiben der Timuridenzeit. Das Šarafnāmä des 'Abdallāh Marwārid (Steiner, 1952). On the people of the sword and pen under the Ak Koyunlu dynasty in Iran, see V. Minorsky, 'A Civil and Military Review in Fārs in 881/1476', Bulletin of the School of Oriental and African Studies 10, no. 1 (1939) 141-178. See for a similar analysis, but from the perspective of the sword, Jos Gommans, chapter 4 in this book.

50 See, for example, Walther Björkman, Beiträge zur Geschichte der Staatskanzlei im islamischen Ägypten (Hamburg, 1928); Adrian Gully, The Culture of Letter-writing in Pre-Modern Islamic Society (Edinburgh, 2008) 131-196; Martel-Thoumian, Les civils et l'administration; Van Berkel, 'Archives and Chanceries'.

51 Joseph H. Escovitz, 'Vocational Patterns of the Scribes of the Mamlūk Chancery', Arabica 23 (1976) 42-62 and Carl F. Petry, The Civilian Elite of Cairo in the Later Middle Ages (Princeton, 1981). 
surroundings of Cairo. ${ }^{52}$ However, the officials' position vis-à-vis the people of the sword underwent considerable change. In many administrative institutions the Mamluks introduced new officials from the military class, who oversaw the people of the pen. Thus a growing influence of the sword over the pen became visible. ${ }^{53}$

The successors of the Mamluks, the Ottomans had extended their empire from Anatolia over large parts of the Middle East. They built on the administrative traditions of the empires they conquered. The degree of centralization they reached by the fifteenth and sixteenth centuries went hand in hand with the development of a centralized administrative apparatus and the recording of the rules underlying the administration in a law code, the kanunname. These developments started under Sultan Mehmed II (r. 1444-1446 and 1451-1481) and reached maturity under his successors. The scale of the Ottoman administration and the extensive use of written records led Rhoads Murphey to argue that it would better to describe this empire, especially after 1550 , 'not as the "gunpowder empire" or as an empire founded on the strength and conviction of the sword, as many have, but to see it as a bureaucratic or paper empire. ${ }^{54}$ However, this does not mean that the sword lost its influence in the Ottoman Empire or that the people of the pen became the dominant group in society. In the highest state institution, the Divan or Imperial Council, the three major groups of the Ottoman Empire were always represented: the people of the sword ('askeri), the people of religious sciences (' ulama'), and the people of the pen. The grand viziers, generally presiding over the Divan as the sultan's deputy, identified with sword and pen and were seen as the head of the bureaucracy and the army. Other crossovers between the three groups seem to have been uncommon. Those who started their careers in judicial positions, for example, generally remained in that field. ${ }^{55}$ During the reigns of Mehmed II and his two successors, the viziers were no longer recruited from the Anatolian Turkish families, but most had a Christian background recruited either through devshirme, the child levy system, or from among the captive or voluntarily transferred former

$5^{2}$ On this tripartite elite, see Petry, Civilian Elite, 312-325.

53 H.L. Gottschalk, 'Dīwān. Egypt', in: B. Lewis, et al., eds., Encyclopaedia of Islam, Second edition (Leiden, 1991) II, 330; Martel-Thoumian, Les civils et l'administration, 35-76.

54 Rhoads Murphey, Exploring Ottoman Sovereignty. Tradition, Image and Practice in the Ottoman Imperial Household 1400-1800 (London, 2008) 253.

55 See, for example, the careers of following famous jurists, Abu al-Su'ud (d. 1574), Kemal Pasha-Zade (d. 1534), and the members of the Fenari-Zade family, who all worked as qadi and/or shaykh al-Islam. I would like to thank Maurits van den Boogert for these references. 
Byzantine and Balkan elites. ${ }^{56}$ The exact balance between pen and sword was constantly changing, depending on political realities, power struggles, factionalism, and individual capacities and rivalries.

In the Divan the people of the pen were represented by the finance ministers, the defterdars, whose numbers grew over time from one under Mehmed II to four by the end of the sixteenth century, and the head of the chancery, the nişancı. ${ }^{57}$ The growing number of financial penmen in the Divan reflects the increasing influence of the financial administration in the course of the sixteenth century. A further indication of the influence of the pen vis-à-vis the sword is that the number of scribes in the central administration remained limited: in the 153 os there were perhaps some 110 in the Divan, who worked under the supervision of a head scribe, the reis ül-küttab. ${ }^{58}$ A list from 1609 mentions some 218 individual penmen with full and permanent positions who were employed as director of a bureau, senior official, or scribal apprentice (for one of these high positions) in the Divan, in one of the bureaus of the financial administration, or in the sultan's private, confidential, secretariat. They were responsible for accounting, auditing, or the official correspondence of the sultan. Not on the salary lists and therefore unknown to us are the lower-level scribes, copyists, and archivists. ${ }^{59}$ The central administration communicated at the local, municipal level, through their local intermediaries, the qadis. ${ }^{60}$

The Ottoman scribes, particularly the higher ranking ones, seem to have been selected according to criteria including specialized knowledge of the scribal rules and regulations, technical competence, and proven trustworthiness through long service. ${ }^{61}$ Both the defterdars and nişancı had received a general education in the madrasa, but then had specialized on-the-job instruction. ${ }^{62}$ Although the growth of the administrative apparatus and the subsequent increasing need for specialists called for officials with specialized training, patrimonial elements such as family and client-patron relations remained

56 Gábor Ágoston and Bruce Masters, Encyclopedia of the Ottoman Empire (New York, 2009) 10-11. See also Metin Kunt and Zeynep Nevin Yelçe, 'Divân-I Hümâyûn: Le Conseil impérial ottoman et ses conseillers (1450-1580)', in: Cédric Michon, ed., Conseils et Conseillers dans l'Europe de la Renaissance v. 1450-v. $155^{\circ}$ (Tours and Rennes, 2012) 301 and 309-313.

Ágoston and Masters, Encyclopedia, 11-12.

58 Ágoston and Masters, Encyclopedia, 12.

59 Murphey, Exploring Ottoman Sovereignty, 256-258.

6o Murphey, Exploring Ottoman Sovereignty, 264-265.

61 Murphey, Exploring Ottoman Sovereignty, 261-262.

62 Kunt and Nevin Yelçe, 'Divân-I Hümâyûn', 302. 
as dominant for one's career perspectives as they had been under the previous Arabic, Persian, and Turkish administrations of West Asia. ${ }^{63}$

The contemporaries of the Ottomans in the east, the Safavids (1501-1722) although traditionally presented as the rulers who revitalized the truly Persian traditions - also clearly inherited from the Turkish, Arabic, and Mongol administrative practices of their predecessors. ${ }^{64}$ Under the early Safavids military, religious, and civil administration often overlapped. The vizier, who headed the administration and was generally of Persian descent, was often overshadowed by officers of the mighty Qizilbash (red-headed) troops of predominantly Turkic-speaking Azerbaijani background, who had helped the Safavids attain power, and by the $s a d r$, who was the centrally appointed head of the religious establishment. ${ }^{65}$ Provincial administration was, for example, for the better part the domain of the Qizilbash, who kept most of its revenues. In the course of the sixteenth century the influence of both the $s a d r$, as head of the religious establishment, and the Qizilbash tribes decreased. Under Shah Abbas (r. 15881629), the vizier became the most powerful official in the administration and more lands came under direct control (and taxation) of the central administration. ${ }^{66}$ The Safavid scribes were generally Persian-speaking and often from families who had served previous dynasties. ${ }^{67}$ The chancery scribe was often referred to by the term munshi. ${ }^{68}$

The last part of this analysis of the administrators of the Islamic world concerns the South Asian experience. In the course of the thirteenth and fourteenth centuries Northern India saw the rise of several Islamic sultanates, the Delhi and Deccan Sultanates, which built their ideas on kingship and good governance on Persian traditions that had reached them through the eastern Persian courts of the Samanids, the Ghaznavids, the Seljuks, and the Ghurids. At the beginning of the thirteenth century, when some of the eastern Iranian centres suffered devastation, many literati and secretaries from this area had moved to Iltitmish' (r. 1210-1236) court in Delhi. These people found high posi-

\footnotetext{
63 Ágoston and Masters, Encyclopedia, 12.

64 Colin Mitchell, The Practice of Politics in Safavid Iran. Power, Religion and Rhetoric (London, 2009) 199 .

65 S. Bakhash, 'Administration vi. Safavid, Zand, and Qajar periods', Encyclopaedia Iranica (Online Edition, 1982) available at http://www.iranicaonline.org/articles/administration -vi-safavid; Lambton, Landlord, 107.

66 Bakhash, 'Administration'; Lambton, Landlord, 105-109.

67 Jean Aubin, 'Etudes Safavids. I. Šāh Ismāīil et les notables de l'Iraq Persan', Journal of the Economic and Social History of the Orient 2, no. 1 (1959) 37-81.

68 On the Safavid munshi and his letter writing, see Mitchell, The Practice of Politics.
} 
tions in the bureaucracy of the sultanate and brought with them their Persian ideas on kingship, good governance, and scribal traditions. They cherished these traditions vis-à-vis large numbers of new comers, naw-musalman, new Muslims of 'base-born' descent including Afghans and Mongols, who entered the sultanate's politics from the second half of the thirteenth century onwards. It is through the eyes of these Persianate literati that we learn about the history of these sultanates. ${ }^{69}$

The successor of the Delhi sultanate, the Mughal Empire, saw new Persianate influxes. Emperor Akbar (r. 1542-1605) was the first to formally declare Persian as the administrative language of the Empire, and he reorganized the administration according to Iranian models. Persian became the language of administration, not only at court, but also at the level of town and village revenue administration. Moreover, Persian became an important language of culture. Persian-writing scribes, also generally referred to by the term munshi or muharrir, were no longer exclusively of Iranian descent. Scribes from the local Hindu communities - especially Khayastas and Khatris, and sometimes Brahmans-frequently staffed the administration. Most of them came from long-standing secretarial families. While they previously had written in Hindavi, they soon learned the Persian language. From the middle of seventeenth century Khayastas and Khatris even became the dominant groups among the munshi class. ${ }^{70}$ The written self-descriptions of these Mughal secretaries have come down to us from the reign of Jahangir (r. 1605-1628). They reflect earlier scribal traditions and cultures, both Islamic, from the Delhi and Deccan Sultanates, and Indic, due to the continuities in recruitment of the Khayastas and Khatris and the translation of many Sanskrit texts such as the Ramayana into Persian. ${ }^{71}$

69 Sunil Kumar, 'Courts, Capitals and Kingship. Delhi and its Sultans in the thirteenth and fourteenth centuries CE', in: Albrecht Fuess and Jan-Peter Hartung, eds., Court Cultures in the Muslim World. Seventh to Nineteenth Centuries (London and New York, 2011) 123143. See also Khaliq Ahmad Nizami, 'Impact of Iranian Traditions on the Administrative Institutions, Concepts and Practices of the Early Delhi Sultanate', in: Khaliq Ahmad Nizami, State and Culture in Medieval India (Delhi, 1985) 142-157.

70 Muzaffar Alam and Sanjay Subrahmanyam, Writing the Mughal World. Studies on Culture and Politics (New York, 2012) 311-315. See also Momin Mohiuddin, The Chancellery and Persian Epistolography under the Mughals: From Babur to Shahjahan, 1526-1658 (Calcutta, 1971).

71 Alam and Subrahmanyam, Writing, 317-318; M. Athar Ali, 'Translation of Sanskrit Works at Akbar's Court', in: Iqtidar Alam Khan, ed., Akbar and his Age (New Delhi, 1999) 171-180. 


\subsection{European Polities}

In post-Roman Europe, officials did not develop a distinct self-conscious identity and professional ethos until the later Middle Ages. In the early and high Middle Ages clerks seem to have identified primarily with other characteristics - regional, familial, clerical — and not with an official scribal position. In those centuries most people of the pen belonged to the clergy, the dominant literate group in society. In the period 1300-160o clerics were still well represented among state officials. Therefore, the balance between book and pen (between religious and scribal elites) was quite different in Europe than in the Islamic and Chinese worlds. While in the Islamic and Chinese territories, the people of the pen kept a certain distance from the religious elites and developed separate self-images, in Europe the pen identified with the book.

The absence of a distinguishable professional image of European officials in the early and high Middle Ages does not mean that there were no ideas on good and bad governance. Advice texts on good rulership built on classical political theories. They referred to the Roman ideas of, for example, Cicero as well as to biblical models. The authors of these texts were the literate elite, the clergy. However, they do not claim a specific professional ethos for officialdom.

This situation slowly started to change in the century before the era under consideration here. In the course of the thirteenth century, following different trajectories throughout Europe, two related developments took place in the administration of European polities that caused the emergence of a new identity for the people of the pen. The first development involved a considerable expansion and intensification of governmental activities. With the increase in judicial, secretarial, and financial functions, the King's councils (Curia Regis) were split up into more specialized institutions such as chanceries, Chambres des Comptes or exchequers, and law courts or Chambres des Conseils. The new institutions moved out of court and obtained a more permanent character. ${ }^{72}$ These developments started in the thirteenth century, and political institutions continued to evolve and expand over subsequent centuries. ${ }^{73}$ By the end

72 Francoise Autrand, Naissance d'un grand corps de l'État. Les gens du Parlement de Paris 1345-1454 (Paris, 1981); idem, Prosopographie et genèse de l'état moderne (Paris, 1986); Mario Damen, De Staat van Dienst. De Gewestelijke ambtenaren van Holland en Zeeland in de Bourgondische periode (1425-1482) (Hilversum, 2000) 33-35; Bernard Guenée, L'Occident aux XIVe et XVe siècles. Les États (Paris, 1971) 181-205; Robert Stein, Powerbrokers in the Late Middle Ages (Turnhout, 2001); John Watts, The Making of Polities. Europe, 1300-1500 (Cambridge, 2009) 205-263.

73 Despite claims by older historiographies that they did come to a halt in the crisis era of the fourteenth and fifteenth centuries only to re-emerge in the late fifteenth and 
of the fifteenth century regnal central administrations prevailed over otherregional, seigneurial, and urban — structures, although these latter contributed considerably to the shaping of the polities. ${ }^{74}$ They had stronger centres and more complex administrations. These changes were structural and took place across the continent. ${ }^{75}$ Growing diplomatic relations increased the exchange of information on administrative practices and ideals between polities throughout Europe. ${ }^{76}$

Obviously, these developments did not take place overnight or across Europe at the same time. In France and England, for example, a permanent council for judicial affairs had emerged by the second half of the thirteenth century. In England, the most centralized state of Europe, we see the development of the Chancery, the Exchequer, and the Privy Seal as permanent, complex, highly specialized professional institutions in the course of the thirteenth and fourteenth centuries. ${ }^{77}$ In the German lands and the Low Countries, on the other hand, overlapping and regionally divergent judicial, secretarial, and financial traditions existed until the fifteenth century. In the Burgundian duchy, for example, it was not until Philip the Good (r. 1419-1467) that these institutions and traditions were streamlined. ${ }^{78}$ Moreover, we should keep in mind that larger, centralized polities were not the only ones at the end of the fifteenth century. In the early sixteenth century some 5oo separate self-governing units existed in Europe. ${ }^{79}$

Developments started with new notions of jurisdiction and law and built on the dissemination of literacy and the increase of the production and keeping of documents..$^{80}$ In addition to the expansion of governmental activity and

sixteenth centuries. See, for example, J.R. Strayer, On the Medieval Origins of the Modern State (Princeton, 1970). Charles Tilly focused in his The Formation of National States in Western Europe (Princeton, 1975) on the period from the late fifteenth century onwards.

74 See, for example, the European projects by Jean-Philippe Genet and Wim Blockmans. See also Watts, The Making of Polities, 29-31.

75 Watts, The Making of Polities, 9, 34-42, 420, 425.

76 Watts, The Making of Polities, 393-419. See also Ralph Griffiths, 'Bureaucracy and the English State in the Later middle ages', in: Francoise Autrand, ed., Prosopographie et genèse de l'État modern (Paris, 1986) 53-65.

T.F. Tout, Chapters in the Administrative History of Medieval England (1920-1933).

78 Watts, The Making of Polities, 394 and 422.

79 Watts, The Making of Polities, 422.

8o On the enormous growth of the use of written records and the development of a literate mentality in England from the twelfth century onwards, see Michael Clanchy, From Memory to Written Record. England 1066-1307 (Oxford 1979, 2nd edition 1993). 
its intrusion in society this period also saw a dramatic increase in the possibilities of communication. Discourses on good governance and political theory, including debates on the bonum commune (the well-being of the people), reached wider audiences. ${ }^{81}$

The second development that stands out in this era is the multiplication of officials and the subsequent emergence of a new type of official, the professionally trained clerk. In the later Middle Ages a group of homines novi, some of them from lay backgrounds and with lower social status than those who had previously been responsible for the writing of the official documents, started to enter the various bureaucracies. These newcomers were, for example, townspeople and lower gentry who had enjoyed a university education or gained secretarial or financial experience in local administrations. ${ }^{82}$ They took care of the administrative tasks in their polities and developed a clear sense of their own role and place in the political whole and their responsibilities for the common good. ${ }^{83}$

These changes in personnel did not mean that clerics and officials of noble origin disappeared from the scene. Both groups were still represented among the high officials who staffed the new institutions. Also the high nobility sent their sons to university for legal training, and patrimonial patterns of recruitment and advancement through existing networks persisted, especially in the chanceries and councils. ${ }^{84} \mathrm{~A}$ good example of the continuance of clerical officialdom can be seen in the 'state prelates' of England and France in the sixteenth century. The number of bishops, cardinals, and other high clerics in governmental service even increased under Francis I (r. 1515-1547) in France and Henry VIII (r. 1509-1547) in England. Indeed, medieval administrations had been well acquainted with clerics at all levels. The early sixteenth cen-

\footnotetext{
81 Watts, The Making of Polities, 135 and 421.

82 Hilde de Ridder-Symoens, 'Training and Professionalisation', in: W. Reinhard, ed., Power Elites and State Building (Oxford, 1996) 149-172.

83 Watts, The Making of Polities, 8-9.

84 See, for example, Mario Damen, 'Serviteurs professionnels et profiteurs loyaux. Hommes d'Eglise au Conseil et à la Chancellerie de Hollande-Zélande (1425-1477)', Publications du Centre Européen d'Etudes Bourguignonnes (XIVe-XVIe s.) 38 (1998) 123-137; idem, 'The Nerve Centre of Political Networks? The Burgundian Court and the Integration of Holland and Zeeland into the Burgundian State, 1425-1477', in: Steven Gunn and Antheun Janse, eds., Court as a Stage. England and the Low Countries in the Later Middle Ages (Woodbridge, 2006) 70-84; Bernard Guenée, Entre l'Eglise et l'État Quatre vies de prélats français à la fin du Moyen âge (Paris, 1987).
} 
tury was, however, characterized by the specific deployment of high prelates as technocrats, specialists of canon and civil law. These prelates received their training most probably in the university, although for France this information is mostly lacking. They were dependent upon the monarchs for their recruitment and advancement, which made them loyal diplomats and administrators. In France the majority of these prelates were of noble origin, while in England this was true for only a small minority. Their background also determined to a large extent their status at court. While French prelates were also courtiers who shared the joys of a courtly life, their English counterparts were technocrats. In England they disappeared from the political scene in the middle of the sixteenth century, but in France it took another hundred years. ${ }^{85}$

Despite these continuities, especially in the higher echelons of the governmental institutions, at the same time a new professional elite emerged in the course of the fourteenth, fifteenth, and sixteenth centuries due to extending bureaucracies. ${ }^{86}$ The professionalization of the administration first emerged in the judicial institutions, soon followed by the chanceries and the financial institutions. Numbers increased rapidly. The officials dealing with the judicial petitions to the French king, for example, increased from four in 1314 to twentynine in 1343, the counsellors of the Parlement tripled in the first half of the fourteenth century, and the notaries in the chancery doubled. The papal Curia, one of the larger bureaucracies in Europe, also doubled in the same period. ${ }^{87}$ The scale of the bureaucracy was determined by the intensity of governmental activities. The bureaucracy of England, for example, was much larger in the fourteenth century than the personnel the emperor had at his disposal. ${ }^{88}$ However, in general throughout Europe the number of administrative personnel grew both at the central and local levels.

The professional personnel needed for the bureaucracies often received training in law at the universities of Bologna, Paris, and Oxford, at the notarial and rhetorical schools, or, on the job in the chanceries and financial institutions of the Papacy and the kingdoms. ${ }^{89}$ These experts entered the regnal admin-

85 Cédric Michon, La crosse et le sceptre. Les prélats d'Etat sous François Ier et Henri VIII (Paris, 2008). See also Andrew Allen Chibi, Henry viII's Bishops: Diplomats, Administrators, Scholars and Shepherds (Cambridge, 2003).

86 De Ridder-Symoens, 'Training and Professionalisation'.

87 Watts, The Making of Polities, 239.

88 Watts, The Making of Polities, 240.

89 Watts, The Making of Polities, 41; Jan Dumolyn, Staatsvorming en vorstelijke ambtenaren in het graafschap Vlaanderen (1419-1477) (Antwerp and Apeldoorn, 2003) 218. 
istrations throughout Europe in the late Middle Ages, but polities followed different trajectories. Legal specialists trained in Bologna and Orléans were, for example, employed in the central administration in France in the first half of the thirteenth century. In the German lands they were not found in the judicial councils until the second half of the fourteenth century. ${ }^{90}$

The officials with a bourgeois background who started to occupy judicial and administrative positions often sought acceptance among the ranks of the hereditary nobility, who had traditionally identified with the sword (noblesse d'épée) instead of the pen. Many of the newcomers, however, never fully integrated with the old military elite, but formed a new group of their own, referred to as noblesse de robe. ${ }^{91}$ Moreover, this was not a linear development towards greater social mobility. While in the thirteenth and fourteenth centuries students from a more modest background could gain a place in society through studies, often through the Church, the universities of the sixteenth century had become meeting places of the nobility and those from the highest layers of the urban elite. ${ }^{92}$

The question is whether these new developments, and especially the emergence of this socially (partly) new and overall growing class of professional officials, coincided with the emergence of a professional ethos and a clearly manifested professional consciousness. French scholars have emphasized how the rise of a new class of state servants in France went hand in hand with the development of strong self-awareness among this group. Françoise Autrand argues, for example, in her study on the men-of-law of the Parisian Parlement between 1345 and 1454, that these councillors and king's advocates consisted of a unified distinct corps with a clear esprit de corps whose main motivation was being loyal to the state. ${ }^{93}$ Similar conclusions are drawn for the other

90 Guenée, L'Occident; Peter Moraw, 'Gelehrte Juristen im Dienst der deutschen Könige des späten Mittelalters (1273-1492)', in: Roman Schnur, ed., Die Rolle der Juristen bei der Entstehung des modernen Staates (Berlin, 1986) 77-147.

91 Bernard Guenée, States and Rulers in Later Medieval Europe, trans. Juliet Vale (Oxford, 1985) 204 .

92 Jacques Le Goff, Les intellectuels au Moyen Age (Paris, 1957); Hilde De Ridder-Symoens, 'Adel en Universiteiten. Humanistisch ideaal of bittere noodzaak?', Tijdschrift voor Geschiedenis 93 (1980) 414-432.

93 Autrand, Naissance, 133-157. See also Guenée, L'Occident; Marcel Pinet, Pierre Riché, Eric Bournazel and Francoise Autrand, Histoire de la fonction publique en France. Tome I. Des origines au Xve siècle (Paris, 1993); Albert Rigaudière, Pouvoirs et institutions dans la France médiévale. Tome II. Des temps féodaux aux temps de l'État (Paris, 1998). 
administrative institutions of the French kingdom and for, for example, the late medieval English bureaucrats who are said to have shared a professionalism and even mutual interests beyond the office. ${ }^{94}$

Others have argued that we should be careful in suggesting the existence of such long modernizing lines of state formation, including the question whether something like a Weberian bureaucratic class with a related ethos actually did emerge, if only because it introduces the dangers of teleology. ${ }^{95}$ They argue for a cautious evaluation of the motivations of this group as straightforwardly loyal towards something as abstract as a state. ${ }^{96}$ They further refer to continuing problems with the venality of offices, a practice that survived for centuries to come.

Despite the ongoing debates and changing perspectives on the processes of state formation and the role of state servants within it, what is not contested is the larger narrative: the period under consideration here witnessed an expansion and strengthening of state institutions and the subsequent growth of a class of specialized and professionalized civil servants. These developments were such that this period makes an excellent case for comparison with the older extensive administrative staffs of the Chinese and Islamic territories.

Common learners perhaps read the Classics, but their aim is just to cull out quotations for us in their examination answers. They use the Classics simply to further their selfish desires for profit or success ... So naturally when they are put in charge of some unit of local government, they fail our expectations and depart from the Way, completely unashamed of their rapacity or pliancy. They give no thought to this matter because they have fallen in with common customs. No wonder the military men and

94 See, for example, Griffiths, 'Bureaucracy and the English State'.

95 For general discussions on state formation, see, for example, Wim Blockmans and JeanPhilippe Genet, eds., The Origins of the Modern State in Europe, 13th to 18th Centuries, 7 vols. (Oxford, 1995-200o); Michael J. Braddick, State Formation in Early Modern England ca. 1550-1700 (Cambridge, 2000); Wolfgang Reinhard, ed., Power Elites and State Building (New York, 1996).

96 See, for example, Philippe Contamine, 'Le Moyen Âge occidental a-t-il connu des "serviteurs de l'État"', Actes des congrès de la société des historiens médiévistes de l'enseignement supérieur public 29e congrès, Pau, 1998. Les serviteurs de l'Etat au Moyen Âge (Paris, 1999) 9-2о. 
clerks deride these low $r u^{97}$ for their usefulness. Yet, surely this is not what the Way of the $r u$ really consists in..$^{98}$

In this quotation, the literatus Cheng Duanli (1271-1345), a teacher in local government schools under the Yuan rulers, characterizes the ideal official. His official is someone who did not learn Confucian thought to get a job, but who has internalized its morals. He advocates the idea that the Way is not just some sort of idle or cosmetic worldview, but that its principles should be applied directly by officials while dealing with their daily tasks. ${ }^{99}$

People of the pen within the Chinese, Islamic, and European territories produced texts that defined and made claims about the professional ethos of the group. These texts reflect upon the role of scribes within society; they lay down the rules and regulations of good writing and administrative ideals and express how they should contribute to the keeping together of empires and polities. This second part analyses the ways in which officials framed their expertise and their moral codes and how they positioned themselves towards other power groups and individuals in society. It will start with an overview of the types of texts in which these self-images appear.

\subsection{Literary Traditions}

Studies on specific texts in which self-images of officials appear or on a group of advice texts from a specific era ${ }^{100}$ demonstrate the obvious need to analyse these texts within the contexts in which they were produced in order to fully comprehend their rhetoric and ideologies. These contexts are related not only to politics and society, but also to genre and style. Within the framework of this comparative study detailed exercises of specific texts, authors, and styles are evidently unattainable. What I will do is specify some general characteristics of the genres in which the self-perceptions of officials appeared. Although all sources are part of a generic group of advice literature, the literary traditions of which they form part differ from area to area and throughout the ages.

97 According to Dardess, $r u$ is a term used for those shi ' whose endeavours featured some sort of intellectual work or "study". While it was understood that among the shih there existed a spatial hierarchy of local, regional, and central types, among the shih-as-ru there was a related but rather different scale of ranking that focused upon depth, motivation, and competence in study.' Dardess, Confucianism, 22.

$98 \quad$ From Cheng Duanli. Translation by Dardess, Confucianism, 31.

99 For other instances in which Cheng Duanli advocates this thought, see Dardess, Confucianism, 64 .

100 See, for example, Heck, Construction of Knowledge, and Mitchell, The Practice of Politics. 


\subsubsection{Imperial China}

Self-images of Chinese literati are advertised in a wide variety of sources. Anthologies, referred to in Chinese as zongji and the related genre of the encyclopaedias referred to in Chinese as leishu, classified writings, were important manuals for literati. These texts are compendia consisting of longer and shorter quotations from earlier, 'classical', prose and verse works as well as from the official dynastic histories. ${ }^{101}$ Encyclopaedias and anthologies first appeared as books of advice (mirrors) for the emperor and his administrators covering literary, historical, philosophical, and administrative themes. Since they describe the ideal moral, social, and educational standards of the literati, they also functioned as textbooks for examination candidates. Some of these texts focus on a specific field such as the literary and lexicographical aspects of the secretarial craft, and served as model books for writing official letters and documents or examination essays. Others provide the beginning student with basic general knowledge or more in particular, the Learning of the Way. ${ }^{102}$ Again others, especially from the Ming onwards, are comprehensive compilations containing 'all that is known' at a certain time. ${ }^{103}$

In addition, poetry, letters, diaries, autobiographical texts and collected writings served as prominent vehicles for articulating a self-image. For the analysis of self-presentations of the Yuan period, I will rely on John Dardess's study Confucianism and Autocracy-Professional Elites and his analysis of 128 collected writings. ${ }^{104}$ The collections Dardess used, mostly written by Southern Chinese Confucian literati, contain a 'nearly full listing of all extant works by writers who flourished between the years 1340 and 1400'. They generally aim at representing a comprehensive overview of all the writings of one individual put together after his death by students or heirs. The length of the papers and the quality varies, but the collections are organized according to categories of

101 Harriet T. Zurndorfer, 'The Passion to Collect, Select and Protect. Fifteen Hundred Years of the Chinese Encyclopaedia', in: Jason König and Greg Woolf, eds., Encyclopaedism from Antiquity to the Renaissance (Cambridge, 2013) 505-528. See also Endymion Porter Wilkinson, Chinese History: A Manual (Harvard, 200o) 593-611; De Weerdt, Competition over Content, 11-12.

102 For the Southern Song Hilde De Weerdt categorized the examination-preparation manuals she used in her study into two categories: encyclopaedias (leishu) and anthologies, the latter being subdivided into numerous types: general ancient prose, general ancient prose notes, anthologies by specific authors, examination essays, learning of the Way manuals, and so on. De Weerdt, Competition over Content, appendix в.

103 Wilkinson, Chinese History, 6o1-6o2; Zurndorfer, 'Passion to Collect', 519-522.

104 Dardess, Confucianism. 
accepted literary genres, including $x u$ ('prefaces' to the works of others; 'messages' to students or acquaintances about to undertake some journey or official mission); ji ('inscriptions' for temples, official establishments, schools, city walls, or the homes, pavilions, and studios of private individuals); lun ('discussions' on various themes, with many related genres); together with colophons to books or paintings; poems; letters; biographical sketches; and epitaphs and other commemorative pieces for the dead. ${ }^{105}$

For self-representations under the Ming regime (1368-1644), I made extensive use of Benjamin Elman's studies A Cultural History of Civil Examinations in Late Imperial China and Civil Examinations and Meritocracy in Late Imperial China. The sources Elman used for his analysis are both private and commercial collections of examination essays of individual literati or groups of literati. More specifically he looks at reports of the civil examinations by examiners, which included the best papers on quotations or questions. ${ }^{106}$ In addition to Elman's analysis of literature by Ming literati, I will use the political treatise Ming yi dai fang lu ('Waiting for the Dawn. A Plan for the Prince') by Huang Zongxi (1610-1695). Huang, a son of a high official of the Ming dynasty, was himself unsuccessful in the civil service examination, but nevertheless became involved in politics, especially as a political critic towards the end of the Ming regime. He remained, however, loyal to the Ming, and from the takeover of the Manchus he refused any official position and concentrated on scholarship instead. Huang wrote many works in the fields of history, philosophy, and literature and compiled many anthologies. Ming yi dai fang lu is his most famous work. Although completed in 1663, Huang collected in it the classical values of literati culture of the past as he perceived it, and he refers mostly to the Ming experiences. ${ }^{107}$

\subsubsection{The Islamic World}

Self-perceptions of the people of the pen in the Islamic world appeared in miscellaneous literary genres. Advice literature for officials appeared beginning in the eighth century in Arabic, and since then a very rich literature developed in the major languages of the Islamic world, Persian, Arabic, and Turkish. Notably, many authors were multilingual. Turkish authors wrote manuals in Persian or Arabic, and authors who wrote in Turkish or Persian quoted Arabic authors, especially their poetry. The example of 'Abd al-Hamid ibn Yahya's

\footnotetext{
105 Dardess, Confucianism, 2-5, 8o-81 and 334-346.

106 Elman, Civil Examinations and Meritocracy, 64-66.

107 Waiting for the Dawn. A Plan for the Prince. Huang Tsung-his's Ming-i tai-fang lu, trans. Theodore de Bary (New York, 1993) 4-8.
} 
treatise mentioned in the introduction shows the interconnectedness of ideas on writing throughout the centuries in the Islamic world. ${ }^{108}$

The most frequently used terms for the genres in which self-definitions of penmen were advertised are adab, akhlaq, and wasiyya. Adab refers to the sum of knowledge that makes a person cultured and thus refers to encyclopaedic or more specialized works on disciplines such as poetry, history, geography, rhetoric, and grammar. It also denotes refinement and urbanity as opposed to uncouthness, and in that context it is used for works on the etiquette of eating, dressing, and conversation. ${ }^{109}$ From these meanings evolved a kind of advice texts for specific professions, containing the rules of conduct and the social and cultural manners of a certain profession, for example: adab al-katib (for the scribe) or adab al-qadi (for the judge).

A work on akhlaq (ethics) emphasizes the personal virtue and good character of the ruler or his servants. ${ }^{110}$ Generally written by important penmen, these texts also voice the self-definitions of the group. The Islamic advice literature built on pre-Islamic Persian and Greek models. Nasir al-Din al-Tusi (d. 1274), for example, referred in his Akhlaq-i Nasiri (Nasirean Ethics) to Platonic, Neoplatonic, Aristotelian, Achaemenid, and Sassanian political theories. ${ }^{111}$

A wasiyya has the connotation of a testamentary advice of a father to his son or an administrator to his heir. A well-known wasiyya is, for example, the treatise Tahir b. al-Husayn (r. 775-822) wrote on the accession of his son as provincial governor in eastern Iran. Other self-images can be found in a much broader corpus of texts, including chronicles, poetry, and collections of allegorical fables such as Kalila wa-Dimna. ${ }^{112}$

The eighth-century treatise by 'Abd al-Hamid set the standard for a series of more elaborate adab al-katib manuals of the Abbasid era such as the famous Adab al-Katib ('The Education of the Scribe') by Ibn Qutayba (d. 889) who elab-

108 Louise Marlow, 'Advice and Advice Literature', in: Kate Fleet, et al., eds., Encyclopaedia of Islam, THREE (2015) http://dx.doi.org/10.1163/1573-3912_ei3_COM_oo26.

109 F. Gabrieli, 'Adab', in: P. Bearman, et al., eds., Encyclopaedia of Islam. Second edition (2012) http://dx.doi.org/10.1163/1573-3912_islam_SIM_o293.

110 F. Rahman, 'Aklaq', Encyclopcedia Iranica, http://www.iranicaonline.org/articles/aklaqethics-plural-form-of-koloq-inborn-character-moral-character-moral-virtue.

111 Linda T. Darling, 'Mirrors for Princes in Europe and the Middle East: A Case of Historiographical Incommensurability', in: Albrecht Classen, ed., East Meets West in the Middle Ages and Early Modern Times. Transcultural Experiences in the Premodern World (Berlin and Boston, 2013) 235-236.

112 Marlow, 'Advice.' See also Beatrice Gruendler and Louise Marlow, eds., Writers and Rulers. Perspectives on Their Relationship from Abbasid to Safavid Times (Wiesbaden, 2004). 
orated on lexicography and grammar, and Qudama b. Ja'far's (d. 948) Kitab al-Kharaj ('The Book of Land Tax') which also dealt with the financial administration of the realm. ${ }^{113}$ The authors of these texts laid down the standards of the administrative practice, the moral codes, and the general cultural capital of the professional group, thus creating and enhancing a group ethos.

After the demise of the political power of the Abbasid caliphs a wide range of later advice works appeared in various successor states. These texts display striking continuities and often quote large parts from the earlier, Abbasid, manuals, but at the same time display clear developments and differentiations. These changes mainly concern the technical aspects of the secretarial work: developments in taxation and judicial practices and, for example, different uses of titles in official correspondence.

In the Mamluk era the genre culminated in voluminous works of an encyclopaedic character such as al-Qalqashandi's (d. 1418) Subh al-A'sha ('Daybreak for the Sufferer of Nightblindness'). It is a massive work comprising, in the standard edition in modern print, more than 6500 pages. It discusses a wide variety of topics including biology, geography, metrics, and history, all of which are considered to be part of the scribe's general cultural training. The largest part is, however, devoted to the writing of the various types of documents emanating from the Mamluk chancery. This part is illustrated with model letters from various eras and areas and interspersed with poetry and quotations from other manuals.

Noticeable are the autobiographical, although often stereotypical, elements in these texts. Al-Qalqashandi, for example, incorporates a treatise, entitled al-Kawa'ib al-Duriyya ('The Shining Stars'), in the Subh al-A'sha in which he outlines his personal doubts and worries about the profession of scribe. Similar descriptions are also found in Ottoman manuals and in the Persian autobiographical texts of the Mughal munshi that focus on the cultural capital and moral universe of these scribes. A good example of the latter is found in the seventeenth-century Tazkirat al-Safar wa Tuhfat al-Zafar ('Accounts of Travels and the Gift of Success') by Nek Rai. ${ }^{114}$

The officials of the Ottoman and Mughal empires produced similar administrative manuals with detailed technical and more general advice for their colleagues. As in the earlier Arabic tradition, some of these texts focus on the epistolary aspects of the penmen's profession such as the anonymous seventeenth-

113 For a more complete overview of adab al-katib manuals from the ninth to the fifteenth century, see Heck, Construction of Knowledge, and Björkman, Beiträge zur Geschichte.

114 Alam and Subrahmanyam, Writing, 319-336. 
century Nigarnama- $i$ Munshi, which deals with the drafting of various types of documents. It contains several model letters by the author and by prominent predecessors. Others concentrate on fiscal administration, such as the Khulasat al-Siyaq by Indar Sen from the early eighteenth century. ${ }^{115}$ The testamentary letter appears in later centuries as well. An example is the letter by the Mughal munshi Chandrabhan 'Brahman' (d. 1662/3) to his son Khwaja Tej Bhan, which deals both with the codes of conduct and the more general cultural capital of the scribe's profession, including a list the books an aspiring munshi should read. ${ }^{116}$ An Ottoman advice text that will be referred to in the following analysis is the Nasihatu s-Selatin ('Counsel for Sultans') by the bureaucrat Mustafa 'Ali (d. 160o). ${ }^{117}$

\subsubsection{Europe}

Compared to the other traditions, self-definitions of bureaucrats are remarkably less prominent in the European sources of the period 1300-1600. However, with the increasing professionalization of the bureaucracy and increase in numbers of bureaucrats in the late Middle Ages, self-images as well as professional instructions started to appear on a modest scale. Self-images were most confidently produced by the judicial administrators of the emerging European states, but manuals for financial and chancery officials also contain elements of professional self-awareness.

Due to the limited number of institutions of higher education, the European scholarly network in the thirteenth and fourteenth centuries was relatively small. Moreover, these scholars worked with the same set of key texts, including, in addition to the Scripture and patristics, the collections of Roman and canon law and a limited set of classical texts. This resulted in the circulation of instructions and ideas on good governance throughout Europe. In the course of the fifteenth and sixteenth centuries this network became larger and officials started writing political and administrative advice texts for a wider audience, not only in Latin, but also in the vernacular. The texts in which the self-images of officials appear most prominently can roughly be classified into two interrelated broader categories: those mainly meant for instruction, containing technical, specialized, knowledge for specific functions within the administration; and, secondly, those providing more general political advice for rulers or high officials.

\footnotetext{
115 Alam and Subrahmanyam, Writing, 318-319.

116 Alam and Subrahmanyam, Writing, 315-317

117 Cornell H. Fleischer, Bureaucrat and Intellectual in the Ottoman Empire: The Historian Mustafa Ali, 1541-160o (Princeton, 1987).
} 
The first category - instruction texts - consists of manuals for the three specializations of state administration: epistolary and rhetorical instructions for chancery scribes, manuals on law practices for judicial officials, and, more sporadically, financial instructions for the officials of the Chambres de Comptes. Sometimes these categories overlap. Manuals for style, grammar, and rhetoric, were, for example, meant for both the chancery scribes and judicial officials. These works are sometimes, but certainly not consistently, labelled under the generic term ars dictandi, books of texts for the discipline of ars dictaminis, the composing of letters and other prose documents. ${ }^{118}$ They consist of either short formularies containing, for example, lists of standard addresses or more extensive textbooks teaching the rules and styles for composing letters, by including extensive collections of model letters and practical information on the use of scripts, seals, and signatures. Other texts were simply anthologies of model letters. ${ }^{119}$ The emergence of treatises discussing the theory of letter writing is linked to the increasing demand for written documents in both church and state administrations. The manuals were first developed in Italy in the late eleventh century and spread to France by the mid-twelfth century and by the end of the twelfth century to Germany and England, each area developing slightly different traditions and adapting the rules to its own demands. A good example of a model book for England is the Formulary by the scribe of the Privy Seal Thomas Hoccleve (d. 1426). ${ }^{120}$ These instruction manuals for composing letters continued to be written until the sixteenth century. ${ }^{121}$

For jurists a whole series of manuals, glosses, and commentaries on both Roman and canon law circulated in late medieval Europe. Jurists further made use of regulations or ordinances discussing procedures, rules of conduct, and division of tasks in the councils. ${ }^{122}$ These ordinances were updated on a regular basis. ${ }^{123}$ In the late fifteenth century jurists of the councils also started to write more comprehensive texts, explaining judicial procedures to a wider audience,

118 Martin Camargo, Ars Dictaminis. Ars Dictandi. Typologie des Sources du Moyen Âge Occidental, fasc. 6o (Turnhout, 1991) 20.

119 Camargo, Ars Dictaminis, 20-28; James J. Murphy, Rhetoric in the Middle Ages. A History of the Rhetorical Theory from Saint Augustine to the Renaissance (Tempe, 2001) 194-268.

120 See also John H. Fisher, The Emergence of Standard English (Lexington, 1996).

121 Camargo, Ars Dictaminis, 29 and 35; Murphy, Rhetoric, 202-203 and 267.

122 Watts, The Making of Polities, 254-259, 381-384, 396.

123 On the Burgundian regulations, see Robert Stein, De Hertog en zijn staten. De eenwording van de Bourgondische Nederlanden. Ca.1380 - ca.1480 (Hilversum, 2014) 177-179. On the ordonnances of the Parisian Parlement on which they are based, see, for example, Autrand, Naissance. 
not only councillors. ${ }^{124}$ These manuals and treatises seem to have functioned as guidelines for, for example, junior jurists. Examples are the Briève instruction and the Practijke civile by the Burgundian councillor Filips Wielant (d. 1520). ${ }^{125}$

Financial officials made use of short checklists and oral instructions. ${ }^{126}$ Some of the Chambres des Comptes seem to have worked with more comprehensive manuals. An example of the latter is the Handboek van de Rekenkamer ('Manual of the Chambre des Comptes') of Rijsel, which has notes from the fifteenth until the seventeenth century. It contains descriptions of the months and seasons, of the earth, planets, and stars. It has lists of exchange rates and contains historiographical descriptions. Penmen's self-perceptions are incorporated in a number of 'memoires' discussing the ethical conduct and general cultural capital of the gens des comptes. ${ }^{127}$

The various instruction texts contain specific guidelines for the various types of officials, and in this way they project an occupational ethos. However, they are very concise when it comes to the definition of a broader self-image of the group and its role in society. This is also true for the second category of texts that will be discussed here, the mirror for princes. Many of the mirrors of this era were written by high officials, often members of the ruler's council. Many others were written by the clergy and not all of them occupied positions in state service. These mirrors were meant for a broader audience than the specialized chancery, financial, or judicial instruction manuals and lists. Although often addressing the ruler or his heir and approaching good governance from his point of view, they advise also on the characteristics of the ruler's ideal servant and as such some of them contain relevant self-perceptions of the penmen.

Mirror for princes is a modern term for a political advice text, which was sometimes referred to as Speculum (mirror) by contemporaries, but more often with titles such as De Regimine, De Eruditione, and De Institutione for texts in Latin and similar titles in vernacular. A special type of mirror text is the advice literature for city magistrates, for example the Italian podestà, which

124 Watts, The Making of Polities, 381.

125 See also Willem van der Tanerijen (d. 1499), Boec van de loopender practijken van der Raidtcameren van Brabant, Willem van den Berge and the Scaecspel, and Jan van den Berghe and his Kaetspel. I thank Robert Stein for these references.

126 I thank Robert Stein for his explanations of the practices of the accountants in the Burgundian Chambre de Comptes.

127 Jan Dumolyn, 'Organische intellectuelen in het politieke lichaam. De staatsideologie van de laatmiddeleeuwse Bourgondische ambtenaar', Revue belge de philologie et d' histoire 83 , no. 4 (2005) 1095-1096. 
contains also instructions on the recruitment of good and loyal officials. Examples include the Tresor by Brunetto Latini (d. 1294) and Liber de Regimine Civitatum by Giovanni da Viterbo (thirteenth century). ${ }^{128}$ The second half of the thirteenth century saw an increase in political advice texts, many of which were written by members of the mendicant orders, such as De Regno by Thomas Aquinas (d. 1244) and De Regimine Principum from 1287 by Thomas Aquinas's disciple, the Augustinian friar Egidius Colonna (Giles of Rome, d. 1316). As in the Islamic world, advice could also be formulated in the form of a letter. An example is John Gower's (d. 1408) Vox Clamantis, written to Richard II, King of England.

More than 25 o mirrors are said to have been written between the thirteenth and the seventeenth century, most of them during the later Middle Ages. ${ }^{129}$ Here a selection has been made of a few mirrors written by officials themselves and containing at least some information on the role and position of the ruler's civil servants. Examples will be drawn from the works of, for the fourteenth century, Philip of Leyden (d. 1382$)^{130}$ and Lucas de Penna (d. ca. 1390), ${ }^{131}$ for the fifteenth century, Guillebert de Lannoy (d. 1462), ${ }^{132}$ Guillaume Fillastre (the

128 On mirrors for magistrates see Heike Bierschwale and Jacqueline van Leeuwen, Wie man eine Stadt regieren soll:Deutsche und niederländische Stadtregimentslehren des Mittelalters (Frankfurt am Main, 2005); Eberhard Isenmann, 'Ratsliteratur und städtische Ratsordnungen des späten Mittelalters und der frühen Neuzeit', in: Pierre Monnet and Otto Gerhard Oexle, eds., Stadt und Recht im Mittelalter: La ville et le droit au Moyen Âge (Göttingen, 2003) 215-479. On the podestà mirrors see David Napolitano, 'The Profile and Code of Conduct of the Professional City Magistrate in Thirteenth-Century Italy' (PhD dissertation, University of Cambridge, 2014) 224-227 and 243-245.

129 For an overview, see W. Berges, Die Fürstenspiegel des hohen und späten Mittelalters (Leipzig, 1938); Eric de Bom, 'Political Advice', in: Sarah Knight and Stefan Tilg, ed., The Oxford Handbook of Neo-Latin (Oxford, 2015); Cristian Bratu, 'Mirrors for Princes (Western)', in: Albrecht Classen, ed., Handbook of Medieval Studies: Terms-Methods-Trends (Berlin, 2010) 1921-1949; Cary J. Nederman, Lineages of European Political Thought: Explorations along the Medieval/Modern Divide from John of Salisbury to Hegel (Washington, DC, 2009). For later mirrors see also Quentin Skinner, The Foundations of Modern Political Thought (Cambridge, 1978).

130 On Philip of Leyden and his De Cura Reipublicae et Sorte Principantes, see Piet Leupen, Philip of Leyden: A Fourteenth Century Jurist (The Hague, 1981).

131 On Lucas de Penna, see Walter Ullmann, The Medieval Idea of Law as Represented by Lucas de Penna (Routledge, 2010).

132 On Guillebert de Lannoy, see C.G. van Leeuwen, Denkbeelden van een Vliesridder. De 'Instruction d'un jeune prince' van Guillebert van Lannoy (Amsterdam, 1975). 
Younger, d. 1473), ${ }^{133}$ and Guillaume Hugonet (d. 1477), ${ }^{134}$ and, for the sixteenth century, Niccolò Macchiavelli. ${ }^{135}$

Finally, as in the Chinese and Islamic worlds, in Europe too self-images of scribes are sometimes found in miscellaneous sources such as poetry and historiographic texts. A good example of the latter is the journal kept by Nicolas de Baye, scribe (graphier) of the Parisian Parlement from 1400 to $1417 \cdot{ }^{136}$ For the former we can consult the autobiographical poetry of the previously mentioned English poet and clerk of the Privy Seal, Thomas Hoccleve (d. 1426). In his poetry he ponders the role of a scribe, his own role, in the unstable administrative apparatus under the Lancastrians. ${ }^{137}$

\subsection{Expertise}

Ideally, the training of a state official was built on three pillars: a general cultural education in, for example, philosophy and history; a more specialized training in scribal, financial, or judicial skills; and a moral upbringing in just behaviour. These three elements of an official's training were interwoven in the advice literature of all three major regions of our research. However, the precise details of the ideal training and expertise differed between regions, authors, and throughout the ages.

\subsubsection{General Cultural Capital}

Throughout Eurasia, state officials claimed a position as scholars. Obviously, the intellectual traditions they referred to differed, but the gist of their message — a state official needs general intellectual and cultural capital—is shared

133 On his Le traittié de conseil, see M. Prietzel, Guillaume Fillastre der Jüngere (1400/07-1473): Kirchenfürst und herzoglich-burgundischer Rat (Stuttgart, 2001).

134 On Guillaume Hugonet, see Anke and Werner Paravicini, 'L'arsenal intellectuel d'un homme de pouvoir. Les livres de Guillaume Hugonet, chancelier de Bourgogne', in: D. Boutet and J. Verger, eds., Penser le pouvoir au Moyen Age VIIIe-XVe siècle. Etudes offertes à Françoise Autrand (Paris, 200o) 261-325.

135 For the Burgundian advice literature, see Dumolyn, 'Organische intellectuelen'; Dumolyn, Staatsvorming en vorstelijke ambtenaren. For the sixteenth century literature, see also Michael Stolleis, Staat und Staatsräson in der frühen Neuzeit. Studien zur Geschichte des öffentlichen Rechts (Frankfurt, 199o).

136 Journal de Nicolas de Baye. Greffier du Parlement de Paris 1400-1417, Alexandre Tuetey, ed., 2 vols (Paris, 1885-1888). De Baye is also one of the main sources for Autrand's Naissance d'un grand corps de l'État. I would like to thank Frans Camphuijsen for referring me to this journal.

137 Ethan Knapp, The Bureaucratic Muse: Thomas Hoccleve and the Literature of Late Medieval England (University Park, 2001). 
by all traditions. It goes without saying that the actual education of scribes, especially those lower on the hierarchical ladder, was often far removed from the ideal standards formulated in advice literature. Yet, I will look into their ideal qualifications and analyse how and why officials constantly insist on and emphasize the need for a general education on top of more technical and specialized training. In other words, the ideal image is epitomized by the highranking men of letters, and the majority of the clerks probably did not live up to this image. ${ }^{138}$

Guillaume Fillastre (the Younger), the fifteenth-century Burgundian bishop and chancellor, had a revealing explanation for the importance of the official's intellectual knowhow. Since the ruler himself is often lacking such knowledge, his officials have to make up for him, he argued. ${ }^{139}$ However, most authors emphasize the necessity for general cultural literacy in the official's fulfilment of his responsibilities: for example, the Mamluk scribe al-Qalqashandi (13551418), who worked in the central chancery in Cairo, mentions in his administrative manual Subh al-Asha training in knowledge of the Qur'an and the prophetic traditions (hadith), political theory, history of past polities, but also falconry and astrology as indispensable for a scribe. ${ }^{140}$ His argument is that a chancery scribe should be familiar with the technical terms of all disciplines and be able to define miscellaneous phenomena in order to be able to write letters to representatives of each social group and discipline using the correct terminology. ${ }^{141}$ In his Subh al-A'sha, al-Qalqashandi therefore not only includes

138 See, for example, on increasing differentiation between the two groups in Song China, James Liu, 'The Sung Views on the Control of Government Clerks', Journal of the Economic and Social History of the Orient 10, no. 2 (1967) 317-344 and for the Ming clerks, see Elman, Civil Examinations, 53. On the differentiation between theory and practice in the seventeenth century, see Étienne Balazs, Political Theory and Administrative Reality in Traditional China (London, 1965).

139 H. Häyrinen, Guillaume Fillastre. Le traittié de conseil (Jyväskylä, 1984) 25. For a similar view by Chinese literati on their emperor's lack of intellectual qualities, see Pines, Everlasting Empire, 94.

140 For a more detailed analysis of the organization of this text, see Maaike van Berkel, 'The Attitude towards Knowledge in Mamluk Egypt: Organisation and Structure of the Subh al-a shā by al-Qalqashandī (1355-1418)', in: Peter Binkley, ed., Pre-Modern Encyclopaedic Texts: Proceedings of the Second coMERs Congress, Groningen 1-4July 1996 (Leiden, 1997) 159-168; Maaike van Berkel, 'Opening up a World of Knowledge. Mamluk Encyclopaedias and their Readers', in: Jason König and Greg Woolf, eds., Encyclopaedism from Antiquity to the Renaissance (Cambridge, 2013) 357-375.

141 Ahmad b. 'Ali al-Qalqashandi, Subh al-a'sha fi sina'at al-insha', Muhammad Husayn Shams al-Din, ed. (Beirut, 1987) I, 181-182. 
elaborate information from miscellaneous disciplines, but also adds a long list of authors and books prospective scribes should read. ${ }^{42}$ The list is divided into seven main categories, each containing a number of disciplines. The first category, adab, deals with disciplines such as lexicography, metrics, grammar, morphology, and calligraphy. The second, the shari'a disciplines, has, for example, reading of the Qur'an, exegesis, transmission of hadith texts, and figh (jurisprudence). Other main categories include natural sciences (with, for example, medicine, physiognomy, and astrology), geometry, astronomy, arithmetic, and 'practical sciences' (such as political sciences, ethics [al-akhlaq], and domestic administration). History and geography are left out because those disciplines are already incorporated in the Subh al-Asha itself. For each discipline in this list al-Qalqashandi mentions several authors and titles.

Two centuries later in a very similar vein, the Mughal munshi Chandrabhan 'Brahman' enumerates in a letter of instruction to his son Khwaj Tej Bhanbut clearly meant for a larger readership - the books his son should read, also explaining why these are essential for his education:

Although the science of Persian is vast, and almost beyond human grasp, in order to open the gates of language one should read the Gulistan, Bustan, and the letters of Mulla Jami, to start with. When one has advanced somewhat one should read key books on norms and ethics, as well as history books such as the Habib al-Siyar, Rauzat al-Safa', Rauzat al-Salatin, Tarikh-i Guzida, Tarikh-i Tabari, Zafar-nama, Akhbar-nama, and some books like these that are absolutely necessary. The benefits of these will be to render your language elegant, also to provide you with knowledge of the world and its inhabitants. These will be of use when you are in the assemblies of the learned. Of the master-poets, here are some whose collections I read in my youth, and the names of which I am writing down. When you have some leisure, read them, and they will give you both pleasure and relief, increase your abilities, and improve your language ... ${ }^{143}$

142 Al-Qalqashandi, Subh al-a sha, I, 538-566. The list is based on Muhammad b. al-Akfani's (d. 1348) Irshad al-qasid and has been translated into French by Gaston Wiet, who identified most of the titles and authors: Gaston Wiet, 'Les classiques du scribe égyptien au Xve siècle', Studia Islamica 18 (1963) 41-80.

143 Translation by Alam and Subrahmanyam, 'The Making of the Munshi', 316. See also the education of Nek Rai, the seventeenth-century member of a family of munshis whose Tazkirat al-Safar wa Thufat al-Zafar ('Accounts of the Travels and the Gifts of Success') Alam and Subrahmanyam discuss in the remainder of the article. 
The disciplines and titles mentioned by Chandrabhan 'Brahman' partly overlap with al-Qalqashandi's list. Both mention texts on statecraft and ethics, and they describe history as a discipline that needs to be mastered by all officials. Poetry, the most prominent genre on the list by Chandrabhan 'Brahman', also figures noticeably in al-Qalqashandi's manual, although less so on his list of books. One of the history books on the list of Chandrabhan 'Brahman' for his son Khwaj Tej Bhan, the Tarikh-i Tabari ('The History of Tabari', also known as 'The History of Prophets and Kings') by the Persian polymath al-Tabari (839923) is also used by al-Qalqashandi in his historical section. References to books on natural sciences, geometry, law, astronomy, and arithmetic do not figure on the list Chandrabhan 'Brahman' put together, but some of these disciplines are mentioned elsewhere in his letter.

Notwithstanding the presence of others with cultural prestige such as Buddhist and Daoist monks, ${ }^{144}$ in imperial China the shi were dominant in the cultural sphere. They self-confidently claimed a position as intellectuals. ${ }^{145}$ Their self-definition included a strong emphasis on abstract, theoretical knowledge. It is especially in their criticisms on the education of their own age that we learn about their ideal expertise. In the fourteenth century under the Yuan dynasty many literati complained about the official (local) schools, which, according to them, only prepared for the civil service examinations. From 1315 onwards, when Ayurbarwada Buyantu Khan (or Emperor Renzong of Yuan), the fourth emperor of the dynasty, reinstated the examination system, training, in the eyes of critical literati, had become artificial and formalized. Students gained superficial knowledge only and lacked any real understanding of the classics. Song Lian (d. 1381), a late-Yuan-early-Ming scholar, who was appointed supervisor of the ruxue or Confucian schools under the first Ming emperor, formulated it as follows:

When the classics are not clearly understood, the mind is not straight, and consequently good customs cannot prevail in the villages nor good order in the state. The good student will lay aside the commentaries and subcommentaries, embrace the bare classics, and internalize them. He makes each word and each phrase soak into his mind. At first it is terribly hard to make headway, but gradually it sinks in and he gets some results.

144 See, for example, Susan Naquin, Peking. Temples and City Life, 1400-1900 (Berkeley and Los Angeles, 2000).

145 Pines, Everlasting Empire, 77. 
Finally, classics and mind become one, and he no longer knows whether his mind is the classics or the classics is his mind..$^{146}$

What were these 'bare classics'? Knowledge of 'a body of abstract, general principles governing human nature and the social system', one of the definitions of neo-Confucianism or 'The Learning of the Way', was considered to be based on the Four Books and Five (or Six) Classics. ${ }^{147}$ Acquiring this knowledge could be achieved through continuous study of these sources and their interrelationship until, as Song Lian pointed out in the quotation above, 'classics and mind become one'. The first combined edition of the Four Books appeared in 1182 edited by Zhu Xi (d. 1200), one of the most prominent literati in the twelfthcentury Learning of the Way movement. The Four Books consisted of The Great Learning, The Analects, Mencius, and The Doctrine of the Mean. ${ }^{148}$ The Five Classics were pre-Qin texts including Classic of Poetry, a collection of poems; Books of Documents, a collection of documents and speeches; Books of Rites, describing ancient rites and ceremonies; Yijing (Book of Changes), a divination text; and Spring and Autumn Annals, the official chronicle of the State of Lu, the home of Confucius. Sometimes the (lost) Classic of Music is added as a Sixth Classic. ${ }^{149}$ Often students also had to study the voluminous Standard Histories (zhengshi), the official history of subsequent dynasties. ${ }^{150}$

This body of knowledge contained not only an intellectual, but also a strong ethical content. Mastery of this knowledge, according to literati, was attainable only through ethical self-development. Wang Xing (d. 1395), a late-Yuan-earlyMing literatus phrased it as follows:

Today's learners read the Classics and yet how many there are who flout the Way in what they write and say. And those shi who don't flout the Way, who ought to be able to approach those of antiquity, don't even do as well as those of the Han. Why is that? What the Song Neo-Confucian fathers spoke of was the mind of the sage, and what they acted upon was the Way of the sage. But [today's shi] repeat the words but don't make that mind their mind; they talk about the Way, but don't make that action

\footnotetext{
146 Translation by Dardess, Confucianism, 161.

147 Dardess, Confucianism, 25-26.

148 De Weerdt, Competition, 34.

149 See Michael Nylan, The Five "Confucian" Classics (New Haven and London, 2001).

150 Endymion Wilkinson, 'Standard Histories', in: Chinese History: A New Manual (Cambridge MA, 2012) 501-515. See also Benjamin A. Elman and Martin Kern, Statecraft and Classical Learnings. The Rituals of Zhou in East Asian History (Leiden and Boston, 2010).
} 
their action. Thus of course they fail to match the ancients. The Way of the sages is not outside the classical texts, yet it cannot be attained by reading and memorization alone. ${ }^{151}$

To the more general knowledge discussed above Benjamin Elman adds the issue of language. After the institutionalization of the Mandarin dialect in Beijing after 1415-1421, officials needed to master this new spoken dialect (northern and southern Mandarin) on top of a written language (classical Chinese) whose symbols and forms required years and years of training, but which had to be mastered to read the classical texts and compose essays. ${ }^{152}$ The details of training in the specific prose style of the '8-legged essay' will be discussed below.

Unlike the numerous references to general knowledge made by officials from the Islamic world and the Chinese territories, European bureaucrats in the period 1300-1600 do not explicitly articulate a self-image of general cultural literacy. However, also in Europe the political theory of the age was based on a series of classical texts, most notably Cicero, and some key texts on canon and Roman law. ${ }^{153}$

Some scholars have tried to reconstruct the general cultural capital of high officials by analysing their libraries. For example, the Flemish jurist Filips Wielant (d. 1520), member of the Great Council of Mechelen, possessed civil and canon law texts and commentaries, philosophical and theological classical texts by Aristotle, Cicero, and Boethius, and, classical and contemporary belleslettres and histories. ${ }^{154}$ Among the books owned by other members of the Council we also find the Church fathers, romances, and moralistic literature. ${ }^{155}$

Others have analysed treatises and speeches by high officials to reconstruct their sources and knowledge of classical texts. Arjo Vanderjagt, for example, reconstructed the speeches of Guillaume Hugonet (d. 1477), chancellor to Charles the Bold of Burgundy, and detected references to and interpretations of Aristotle, pseudo-Aristotle, Cicero, Seneca, pseudo-Seneca, Augustine, Oro-

151 Translation by Dardess, Confucianism, 3 о.

$15^{2}$ Elman, Civil Examinations, $48-5$ o.

153 On editions of Cicero's De oratore and De officiis in the Renaissance, see, for example, David Marsh, 'Cicero in the Renaissance', in: Catherine Steel, ed., The Cambridge Companion to Cicero (Cambridge, 2013) 306-317.

154 D. van den Auweele, Gilbert Tournoy and Jos Monballyu, 'De bibliotheek van Mr. Filips Wielant (1483)', Lias: Sources and Documents Relating to the Early Modern History of Ideas 8 (1981) 146-187.

155 Dumolyn, 'Organische intellectuelen', 1098. 
sius, Caesar, and Lactanius, and, more recent authors, such as the Italian jurists Bartolus de Saxoferrato (d. 1357) and Baldus de Ubaldis (1400). ${ }^{156}$ This does not mean, however, that Hugonet actually read all of these texts; he may also have used some of the florilegia that circulated in his milieu. In his allegorical work on judicial practices, Kaetspel, Jan van den Berghe refers to the poetry of Petrarch on top of a long list of classical and medieval authors. ${ }^{157}$

\subsubsection{Specialized Training}

The proper balance between general knowledge and specialized expertise was debated by officials throughout Eurasia. In his Waiting for the Dawn, the seventeenth-century Chinese author Huang Zongxi frequently emphasizes the importance of practical ability and of the proper actual conduct of affairs in addition to the so broadly appreciated general scholarly knowledge. ${ }^{158}$ The Ottoman official Mustafa 'Ali of Gallipoli (d. 160o), on the other hand, complained a century earlier about the new generations of officials trained in specialized bureaucratic procedures, but lacking any broader cultural knowledge. ${ }^{159}$ Yet most officials seem to have agreed on the value of some sort of combination of general and specific knowledge. This paragraph will deal with the officials' views on specialized training.

In their self-descriptions both the literati of the Chinese territories and most officials of the Islamic world emphasize expertise in writing as one of the main features of their training. Al-Qalqashandi's Subh al-A'sha, for example, like most of the manuals of his predecessors, contains sections in praise of writing in general and bureaucratic writing in particular, on correct language (lexicology, orthography, morphology, and grammar), and on endless technical aspects of writing and penmanship, including descriptions of different kinds of pens and how one should use them, ink and the way it has to be preserved and used, different types of forms and sizes of paper, and the various scripts and styles used in the chancery.

In his maqama, entitled al-Kawakib al-Duriyya ${ }^{160}$ al-Qalqashandi sets forth the musings of a fictional scholar, named al-Nathir ibn Nazzam (literally mean-

\footnotetext{
${ }_{15} 6$ Arjo Vanderjagt, 'Frans-Bourgondisch geleerde politici in de vijftiende eeuw', Theoretische Geschiedenis 16 (1989) 406-408. See also Dumolyn, 'Organische intellectuelen', 1097.

157 Dumolyn, 'Organische intellectuelen', 1097. See also Dumolyn's description of high officials as intellectuals, Dumolyn, 'Organische intellectuelen', 1099-1102.

$15^{8}$ De Bary, 'Introduction' to Waiting for the Dawn, 36.

159 Fleischer, Bureaucrat, 9 .

160 Known to us through its inclusion in Subh al-asha, XIV, 127-145.
} 
ing: prose-writer son of a poet), who has to make a choice between the pursuit of knowledge and the need to earn his daily bread:

I became distressed, incapable of anything. And I remained perplexed, not knowing which of the two trajectories in life [seeking knowledge or making a living] would be more suitable. For if I should make the pursuit of knowledge my living, I would act reprehensibly in my recourse to knowledge, and if I should spurn earning my living in favour of study, I should perish of need and die of hunger. ${ }^{161}$

Then al-Nathir ibn Nazzam hears a voice reciting verses on the excellence of the position of katib (literally writer, meaning state official) and even quoting the Qur'an: 'Recite, for thy lord is the most generous, who taught the use of the pen, who taught men what he did not know' and 'By the pen and what they write, Thou, by the bounty of thy Lord, art not mad' and 'But over you are guardians, noble ones, writing down'.162 Now al-Nathir ibn Nazzam realizes that the only profession beneficial to the mind of the scholar is that of katib, more specifically, the only acceptable formal activity for a scholar is that of insha', the writing of state documents.

The seventeenth-century Mughal munshi Nek Rai also begins his autobiographical text Tazkirat al-Safar wa Tuhfat al-Zafar ('Accounts of Travels and the Gift of Success') by praising the pen. However, not all officials seem to have ignored the financial skills needed for the job. Nek Rai's contemporary Chandrabhan 'Brahman', describing the ideal munshi to his son, mentions accountancy (siyaq) and scribal skill (nawisindagi) in the same sentence, arguing that 'a man who knows how to write good prose as well as accountancy is a bright light even among lights.'163 He adds that scribes who know accountancy on top of good writing are, unfortunately, rare.

Also the Chinese literati emphasized throughout the centuries a preference for language and writing skills. The learning of classical Chinese required great discipline. Mastering this language was a prerequisite for each official. Prospective officials were expected to be trained in the art of calligraphy, a prominent

161 Translation by C.E. Bosworth in 'A Maqāma on Secretaryship: Al-Qalqashandī's al-kawākib al-duriyya fíl-manāqib al-badriyya', Bulletin of the School of Oriental and African Studies 27, no. 2 (1964) 295 .

162 From subsequently Quran, surat al-'alaq 3-5, surat al-qalam 1-2, and surat al-infitar, 10-11. See also Bosworth, 'A Maqāma', 296.

163 Translation by Alam and Subrahmanyam, 'The Making of the Munshi', 316. 

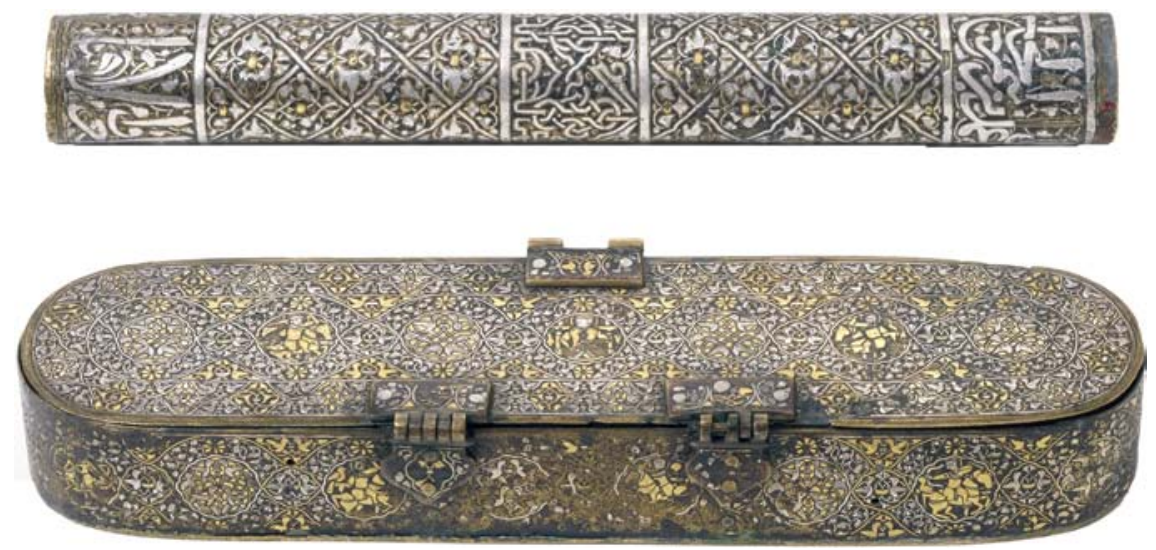

FIGURE 5.1 Document-holder and pen-box of brass, incised and inlaid with gold and silver. Syria, first half of the 14th century. The David Collection, Copenhagen, 4/1976 and 26/1970.

PHOTOGRAPHED BY PERNILLE KLEMP

skill also in the European and West Asian education of scribes. The 'four treasures' of the literatus were his brush, ink, inkstone, and paper. ${ }^{164}$

The focus of the Chinese examination curriculum in this period was prose writing, in particular the famous essay on the Four Books and Five Classics. After having completely disappeared in the first Ming provincial and metropolitan examinations of 1370 and 1371, poetry came back on the exam programmes in the eighteenth century. ${ }^{165}$ However, it always had remained popular outside the exams, specifically as a marker of a man of culture. The literary style that became dominant under the Ming and was tested in the examinations was the essay, which had its roots in the classical essay of the eleventhcentury reformer Wang Anshi (d. 1086). This type of essay, the so-called 8legged essay due to its division in eight sections, remained in use in subsequent centuries. ${ }^{166}$

For the Chinese imperial examinations, fiscal, legal, and other technical and practical skills were only of secondary importance. In early Ming examinations judicial terms (panyu) had been introduced in response to a complaint by Emperor Zhu Yuanzhang on the candidates' lack of practical training. From

164 See also Craig Clunas, Superfluous Things: Material Culture and Social Status in Early Modern China (Honolulu, 1991).

165 Elman, Civil Examinations, 3.

166 Elman, Civil Examinations, 53-54, for more details on the style of these essays, see also the rest of Elman's chapter. 
1381 onwards, all official students had had to study the Ming Code. The technicalities of legal, medical, and fiscal skills were not examined. Training in these fields became the prerequisite of the non-shi scribes: commoner clerks, yamen (administrative office) secretaries, official aides, and Muslims: officials, in short who did not define the characteristic of the self-images of the literati. ${ }^{167}$

Through the overwhelming emphasis by officials of both the Islamic and Chinese territories on good writing instead of, for example, skilful accounting - another obvious field of bureaucratic expertise - the epistolary men, the men of letters, epitomized the ideal image of the group as a whole at the expense of their, in daily life probably much more useful and sometimes better paid, financial counterparts. In the Arabic literary tradition, the antithesis between financial and epistolary officials was a topic of debate from the late Umayyad until the Mamluk period. As all of these polemics were written by officials of the chancery, the winner of the literary debate was always this epistolary katib. He is presented as the most prestigious, influential, and erudite of the two. ${ }^{168}$ An example is al-Hariri's (d. 1122) twenty-second maqama ('assembly'):

Know that the art of insha' (the composition of state documents and letters) is the loftier, although the art of accountancy (hisab) may be more useful. The pen of correspondence is pure eloquence, but the pen of accountancy picks up phrases indiscriminately. The artistic creations of rhetoric are copied down for further study, but the registers of accounts are soon closed up and then destroyed. ${ }^{169}$

The Ottoman official Mustafa 'Ali (d. 16oo) also clearly favours the chancery scribe over his financial colleague. In his opinion it is the chancellor who symbolizes the ideal official, the learned and cultured man of letters. Mustafa 'Ali witnessed the expansion of the Ottoman bureaucracy and with it the emergence of a new type of official, one who had not necessarily received his training in the madrasa, but had climbed the ladder through training on

167 Elman, Civil Examinations, 53.

168 The best known text in this genre is al-Tawhidi's (d. 1023) Al-imta' wa-l-mu'anasa which is translated by Geert Jan van Gelder, 'Man of Letters v. Man of Figures. The Seventh Night from al-Tawhīin̄'s al-Imtā' qa-l-mu'ānasa', in: H.L.J. Vanstiphout, et al., eds., Scripta signa vocis: Studies about Scripts, Scriptures, Scribes and Languages in the Near East, Presented to J.H. Hospers by his Pupils, Colleagues and Friends (Groningen, 1986) 53-63.

169 This maqama is quoted by al-Qalqashandi, Subh al-asha, I, 34 and XIV, 125-126. Translation by Bosworth, 'A Maqāma', 293-294. 
the job. While previously both the financial and epistolary officials had been recruited from one and the same pool, the elite educated in the madrasa, the newcomers of the second half of the sixteenth century who were educated outside the madrasa found their way to the top of the bureaucracy, especially in the financial services. Moreover, from the mid-sixteenth century onwards a financial career provided more opportunities. ${ }^{170}$ 'Ali comments on these developments:

The Chancellors of the Council are the jurisconsults of the imperial law. Therefore, they are to be given more respect and shown more kindness than other high officials. It is particularly necessary to give them honour and precedence over the directors of the financial services. The latter are in the service of money and property, the vain foolishness of this world, while the chancellors are those who guard the secrets of the varieties of imperial edicts which concern justice and equity, and matters of public jurisdiction. ${ }^{171}$

The dichotomy between chancery scribes and their financial counterparts is a topos in many Islamic literary traditions. However, we should keep in mind that most of the administrative manuals were written by chancery scribes, and it is through their eyes that we learn about the relationship between the two types of officials. Some financial officials of the Islamic world also produced manuals. These texts do provide information on the practical technicalities of their tasks-for example dealing with arithmetic formulae, fiscal jurisprudence, or practical tax regulations-but lack broader self-definitions of the group as a whole. ${ }^{172}$

The dichotomy between the chancery scribe and his financial colleague is less evident in the self-perceptions of Europe's officials. Nevertheless, a strikingly similar example is the journal kept by Nicolas de Baye, the scribe (graphier) of the Parisian Parlement. Nicolas de Baye notoriously complains about his financial colleagues in the Chambre des Comptes. ${ }^{173}$

As we have seen, specialized instruction texts for epistolary and financial officials also existed in the European literary traditions. Manuals for chancery

170 Fleischer, Bureaucrat, 215-224.

171 Translation by Fleischer, Bureaucrat, 228.

172 See, for example, Hassanein Rabie, The Financial System of Egypt A.H. 546-741 / A.D. 11691341 (Oxford, 1972). For an earlier period, see also, for example, Qudama b. Jaffar (d. 948), Kitab al-Kharaj.

173 See on his complaints Graeme Small, Late Medieval France (Houndmills, 20o9) 32-33. 
clerks discuss the rules and styles for composing letters, standard addresses, and information on scripts. Sometimes they include a number of model letters. ${ }^{174}$ It can be argued in this way that they present an image of expertise in writing. However, they seem to do so for the purpose of instruction without arrogating a certain status and position, and they refrain from presenting a characterization of the professional group as a whole as experts in writing.

More explicit expressions of identity are to be found among the judicial officials, the legal experts of the ruler's council who often had received their education at one of Europe's universities. Their self-images are mostly found in the advice texts they wrote for their rulers, the mirrors for princes. Examples are Lucas de Penna (d. ca. 1390) and Guillebert de Lannoy (d. 1462) and, much earlier in the thirteenth century, the Tuscan Giovanni da Viterbo. Giovanni da Viterbo mentions expertise in dictation and proficiency in writing as indispensable skills for the Italian notary. ${ }^{175}$ Françoise Autrand, for the members of the Parisian Parlement, and Jan Dumolyn, for the Burgundian high officials, argue that this new class of professionally trained jurists became the main advertisers of a professional ethos and consciousness. However, in comparison to the selfimages of East and West Asian officials, the European officials have less interest in internal specializations and training. They focus on general political theory instead.

\subsubsection{Just and Ethical Behaviour}

According to the late-fifteenth-early-sixteenth-century Florentine official Niccolò Machiavelli (d. 1527), the qualities of a ruler can be judged by looking at his entourage. When his officials are 'capable and loyal', the ruler must be wise, since he apparently knew how to 'recognize their capacities and keep them loyal'. However, if they are not, judgement on the ruler must be negative, because 'the first error he makes is made in this selection.. ${ }^{176}$

No wonder that almost all mirrors for princes, both from the European and the Islamic worlds, advise the ruler on the selection of just and loyal officials. When written by officials themselves these advices contain ideal self-images of ethically correct behaviour. How can a prince recognize a just official? What are his characteristics? According to Machiavelli, it is simple. A good official is the one who does not think about himself and does not seek self-interest:

174 Camargo, Ars Dictaminis, 20-28; Murphy, Rhetoric, 194-268.

175 See Napolitano, 'The Profile', 225.

${ }_{176}$ Niccolò Machiavelli, The Prince, trans. Peter Bondanella (Oxford, 2005) 79. 
For a man who holds the state of another in his hands must never think about himself, but always about his prince, and he must never be concerned about anything that does not concern his prince. ${ }^{177}$

Machiavelli was not the first official from Florence to phrase the moral obligations of his profession in a mirror text. Two centuries earlier, a judge from the same city, Giovanni da Viterbo, pictured the ideal character and attitude of the members of the entourage of the podestà, the city magistrate, in even much more detail than his famous successor. In his Liber de Regimine Civitatum in which the judge takes centre stage, he argues that this official should be morally discerning, God-fearing, sober, and chaste. Another Florentine city magistrate, Brunetto Latini, who underlines the importance of the notary in city administration, argues that the latter should similarly be prudent and incorruptible. ${ }^{178}$

The ideal qualities these mirror texts emphasize differ, but their main message is always the importance of loyalty and trustworthiness. The Burgundian high official Guillebert de Lannoy laid most emphasis on non-corrupt behaviour. ${ }^{179}$ Others use the cardinal virtues, justitia, prudentia, temperantia, and fortitudo, which had been rephrased as political virtues in mirror texts by Thomas Aquinas and Christine de Pisan (d. 1430), in their own political and bureaucratic discourses. ${ }^{180}$ The public guidelines on judicial procedure for junior jurists outside the council such as the manuals by Filips Wielant (d. 1520), Briève instruction and Practijke civile, further emphasize the need for professional solidarity and harmony among officials. ${ }^{181}$

Group consciousness and loyalty towards the other members of the occupation also belong to the scribe's moral codes described in the manuals of the Mamluk and Ottoman officials. In the famous Umayyad treatise by 'Abd alHamid that was copied and referred to in many later manuals, solidarity within the group is phrased as follows:

\footnotetext{
177 Translation by Bondanella in Machiavelli, The Prince, 8o.

178 Napolitano, 'The Profile', 224-227 and 270.

179 See van Leeuwen, Denkbeelden, 83, 91 and 99. On accountability, see also John Sabapathy, Officers and Accountability in Medieval England 1170-1300 (New York, 2014).

180 Dumolyn, 'Organische Intellectuelen', 1094. For adjustments in this discourse, see van Leewen, Denkbeelden, 58 . On the role of late medieval jurists in the formulation of political thought, see Joseph Canning, A History of Medieval Political Thought 300-1450 (London and New York, 1996) 161-167.

181 See also Willem van der Tanerijen (d. 1499), Boec van de loopender practijken van der Raidtcameren van Brabant, Willem van den Berge and Scaecspel, and Jan van den Berghe and his Kaetspel.
} 
If times go hard for someone among you, be kind to him and console him, until everything is well with him again. Should old age make one of you unable to get around and pursue his livelihood and meet his friends, visit him and honour him and consult him, and profit from his outstanding experience and mature knowledge. Each of you should be more concerned for those who treated you well and helped you in your days of need, than for your own children or brothers. ${ }^{182}$

However, for others these high expectations on solidarity triggered mockery. The satirical treatise Fi Dhamm Akhlaq al-Kuttab ('On Criticising the Morals of Scribes'), ascribed to al-Jahiz (d. 868/869), for example, mocks the scribes' internal loyalty by calling them the least inclined to mutual sympathy, saying: 'in your mutual hostility and anger you resemble children of concubines and of mothers who are rival wives'.183

Besides mutual loyalty, the Mamluk scribe al-Qalqashandi includes in his Subh al-Asha a broad range of more general ethical qualities an official should aspire to. He should be of firm will ('azm), of high-aiming ambition (himma), and competence (kifaya). Further instructions concern the good manners he should display in his contact with others, superiors, inferiors, and equals and on the discretion he needs to fulfil his job. ${ }^{184}$ Discretion and the keeping of the ruler's secrets is a recurring topic in mirror literature throughout the Islamic world. It will be discussed in more detail in the next section.

The self-perceptions of Chinese literati are first and foremost a reflection on morally upright behaviour. The status of the shi was defined by behavioural patterns achieved through self-cultivation and learning. ${ }^{185}$ Public-mindedness and commitment to the universal good figured prominently in their self-definitions, as did dutifulness and righteousness. ${ }^{186}$ Shi would seek a career as official for his moral self-realization instead of for its material benefits. ${ }^{187}$

The strong ethical principles that were supposed to guide the acquisition of knowledge for the 'The Learning of the Way' literati under the Yuan and Ming rulers have already been discussed in the section on the general cultural capital

182 'Abd al-Hamid b. Yahya, 'Risala ila l-kuttab', 174. Trans. Franz Rosenthal in Ibn Khaldun, The Muqaddimah, abridged by N.J. Dawood (Princeton, 1989) 204, with some modifications.

183 A darra is a fellow or rival wife in a plural marriage. Al-Jahiz, 'Dhamm akhlaq al-kuttab', in: J. Finkel, ed., Three Essays (Cairo, 1926) 46-47.

184 Al-Qalqashandi, Subh al-a sha, I, 93-122.

185 Pines, Everlasting Empire, 78-79.

186 Pines, Everlasting Empire, 79-80.

187 Pines, Everlasting Empire, 82. 
of officials. Here some of their views on and continuous concerns about corrupt behaviour and the subversion of the moral good will be given. While many of them accepted a certain differentiation in the distribution of talent among its members, uniformity was, however, indispensable in their ethical behaviour. Zhu Tong (d. ca. 1383), a literatus from a family of officials from Xiuning, argued:

We should none of us engage in luxurious habits or corrupt behaviour, or propose what is unorthodox, for the sake of fame, or pervert the Way $(\mathrm{Dao})$ for the sake of agreement, or calculate private profit. This is what we adhere to. ${ }^{188}$

Accusations of corruption and lack of morally upright behaviour were a powerful instrument to discredit one's political enemies. According to many Han Chinese literati, the later Yuan leaders and their military were utterly corrupt and this behaviour negatively influenced local officials. Chen Gao (d.1367) from Pingyang phrased it as follows:

The military personnel are addicted to violence and tyranny and have no concerns for the people's sufferings. At every moment they put demands on the local officials, and humiliate and maltreat them if they fail to respond with alacrity. Consequently, even those local officials who are known for resolution and fearlessness have no way to resist, and have no choice but to alleviate their own problems by placing ruinous demands upon the people. Daily they apply lashes to wounded skins and bodies and see to it that the exactions are made. On top of this, the corrupt connive in evil and the people are put in further straits. ${ }^{189}$

In short, according to Chen Gao and many of his contemporaries, the harsh late-Yuan rulers and their violent military forces influenced the behaviour of officials. The latter seem to have adopted the corrupt behaviour of the former in their own dealings with the people. According to the Han Chinese literati, this led to the decline of the barbarian empire of the Yuan.

188 Translation by Dardess, Confucianism, 23.

189 Dardess, Confucianism, 71. 


\subsection{Social Awareness}

The ruler resembles the head, the senate [council] takes up the position of the heart, from which good and bad initiatives flow, the provincial juridical and political authorities lay claim to the functions of eyes, ears, and tongue. Officials and military, ever supporting the ruler, can be equated with the arms. ${ }^{190}$

The well-known body metaphor articulated here by the fourteenth-century Italian official and jurist Lucas de Penna ${ }^{191}$ not only outlines the interdependence of centre and provinces of the polity but also of the three powerful institutions that will be discussed in this chapter: the ruler, the military, and the officials. The relations between the three will be portrayed from the perspective of the officials. Officials not only formed one of the prominent power groups in imperial politics throughout Eurasia; they were also among the leading authors chronicling the vicissitudes of their polities. Therefore, they constitute our main point of reference on other individuals and groups in society. In other words, our view of these others is greatly coloured by what the people of the pen said about them, by the prejudices they had, the advices and views they wanted to advertise, and, not least, by the way they saw their own position in relation to those others. In their self-definitions, officials frequently refer to the ruler and the military. This chapter will analyse how they positioned themselves vis-à-vis these two other powerholders at court.

\subsubsection{The Official and the Ruler}

In both the European and Islamic traditions the metaphor of the state as the human body is ubiquitous. While the ruler is the head, the officials are presented as the eyes, ears, or tongues, but often also as the limbs of the human body. In his fourteenth-century maqama, the Mamluk scribe al-Qalqashandi sees scribes as 'the far-seeing eyes of kings, their all-hearing ears, their eloquent tongues and their all-embracing intelligences'. ${ }^{192}$ The Umayyad scribe 'Abd al-

190 Princeps obtinet instar capitis, cordis locum senatus habet, a quo bonorum et malorum procedunt initia. Occulorum, aurium et linguae officia sibi vendicant judices provinciarum et praesides. Officiales et milites, qui semper assistunt principis lateribus, bracchiis assimilantur. C.12. For the translation I would like to thank the input of Peter van der Eerden. See also Ullmann, The Medieval Idea, 165.

191 See, for example, Ernst Hartwig Kantorowicz, The King's Two Bodies: A Study in Medieval Political Theology (Princeton, 1997 [1957]).

192 Translation by Bosworth, 'A Maqāma', 296. 
Hamid b. Yahya, to whose work al-Qalqashandi refers and whose text is copied by, amongst others, the famous fourteenth-century historian and official Ibn Khaldun (d. 1406) added the metaphor of the limbs as well:

Your position with regard to rulers is that you are the ears through which they hear, the eyes through which they see, the tongues through which they speak and the hands through which they touch. ${ }^{193}$

In the Chinese tradition we find different, but analogous metaphors. The ruler, the officials, and the common people are compared to streams of water. The Yuan literatus Liu Ji (d. 1375), who retired from service in 1357 to concentrate on his scholarship, describes it in his Yu li zi as follows:

The Son of Heaven is the ocean, the grandees and high officials are rivers and streams, the local officials are creeks, and the common people are springs and rivulets. There is an enormous distance between the rivulets and the ocean, and yet they always flow towards it. ${ }^{194}$

In their collected writings many literati specifically stress their direct access to the court by including answers to the emperor's questions on the classics, letters to the throne, or poems describing certain events at the court. ${ }^{195}$ Access to the emperor obviously stood for influence and prestige.

Loyalty and harmony constituted a two-way process and had to be maintained in some way or another. Many advice texts emphasize the ruler's task to make sure his officials are protected and uphold their integrity. Niccolò Machiavelli described this interdependence as follows:

On the other hand, the prince should be mindful of the minister so as to keep him acting well, honouring him, making him rich, putting him in his debt, giving him a share of the honours and responsibilities; so that the minister recognizes that he cannot exist without the prince, so that the many honours he has, prevent him desiring more, so that the abundance

193 Ibn Khaldun, The Muqaddimah. An Introduction to History, trans. Franz Rosenthal (Princeton and New York, 1967) II, 29-30.

194 Translation by Dardess, Confucianism, 138 .

195 David Robinson, 'The Ming Court', in: David Robinson, ed., Culture, Courtiers and Competition. The Ming Court (1368-1644) (Cambridge Mass. and London, 2008) 29. 
of his wealth will stop him desiring more riches, and so that his many offices will make him fearful of change. ${ }^{196}$

In these examples the relationship between rulers and officials is portrayed as one of loyalty and harmony. The ruler is the head or the ocean, the officials are the intermediaries through which the ruler observes the world and communicates to his people. The (implicit or explicit) claim of all these descriptions seems to be that as long as the officials and the ruler relate to one another in a harmonious way, the polity will thrive.

However, not all texts about the relationship between rulers and officials are as positive as the previous examples. Loyalty is still present in Nasir alDin al-Tusi's description, but in his case not based on harmony and respect but motivated by fear, political pragmatism, and survival strategies. In his Akhlaq-i Nasiri, Tusi advises the official to avoid criticizing a ruler or speaking about his flaws. If an official does so inadvertently, however, 'let him not confess, even though a report may have reached the master-for there is a great discrepancy between a report and an admission'. ${ }^{197}$ Disdain towards the ruler and political pragmatism are also apparent in the extract Tusi copied from the treatise alAdab al-Kabir by the famous Arabic-writing Persian scribe and literator Ibn alMuqaffa (d. ca. 756) who served under the late Umayyads and early Abbasids:

The conditions attached to the service of kings are as follows: the training of the soul to what is distasteful; agreeing with them even in despite of one's own opinion and determining affairs in accordance with their fancies. ${ }^{198}$

And while Tusi still emphasizes the necessity of loyalty despite disagreement, others take a step further and stress the obligation of an official to criticize the ruler. Criticism is most conspicuous in the self-definitions of the Chinese literati. In The Everlasting Empire Yuri Pines sketches an image of the shi on the eve of the imperial unification (by the end of the Warring States period) as an extremely proud and self-confident group of people who position themselves in a haughty way vis-à-vis the ruler. According to Pines, the tensions between, on the one hand, the shi's arrogance and the disdain they felt for the rulers, and, on the other hand, their political dependence upon him, 'was to inform the

196 Translation by Bondanella in Machiavelli, The Prince, 8o.

197 Translation by Wickens, Nasirean Ethics, 239.

198 Translation by Wickens, Nasirean Ethics, 241. 
lives of Chinese intellectuals for millennia to come.' ${ }^{199}$ Pines even cites the view of the prominent Chinese intellectual and political historian Liu Zehua, who claimed that the tensions that the imperial literati felt when serving the throne while keeping an independent critical attitude triggered a kind of psychosis. ${ }^{200}$ Whether these tensions actually informed the lives of literati throughout the centuries is difficult to determine. What we do see, however, is that the tensions became in some way or other a literary topic in their self-definitions.

One of the ideals formulated to relieve this tension was the withdrawal from public service either not to return at all or as a temporary measure to protest against corruption at the court and demonstrate one's own integrity. The ideal of withdrawal from society was used as an effective form of political protest, which was formulated during the first millennium but kept its attractions in the centuries to come and became a recurring theme in the literati's selfrepresentations. Yet, not everyone was positive about this ideal of seclusion. The Yuan literatus Liang Yin (d. 139o) condemned withdrawal from service in an essay on how to act as a good Confucian in times of civil crisis such as the late Yuan period:

Now, some argue that it is definitely a good thing when the shi as recluse disdains both renown and turmoil and abides in carefree non-involvement, because in that way he can regulate his seven emotions and preserve his Heaven-given nature. When he comes forth to serve a ruler and regulate the people, it will be because his loyalty and his desire for success and fame have been aroused. He will find himself in turmoil rather than in ease. He may exhaust his energy and his spirit. How can he prolong his life this way?

I would simply say that 'prolonging life' demands doing what must be done. It certainly does not mean disobeying Heaven in one's own selfish interest. $^{201}$

Another way of dealing with the tension between self-confidence and subservience and between the obligation to serve and the willingness to criticize the actual political reality was to confront the emperor and formulate criticism. There are numerous examples in Chinese imperial history of literati who criticized the emperor, in veiled language or openly. Famous for its open

\footnotetext{
199 Pines, Everlasting, 81.

200 Pines, Everlasting, 95.

201 Translation by Dardess, Confucianism, 95.
} 
and comprehensive criticism is the case of the Ming official Hai Rui (d. 1587) from Hainan. Known for his uncompromising attitudes and integrity, in 1565 he wrote a memorandum for Emperor Shizong (r. 1521-1567) in which he criticized him for forsaking his duties. Shizong felt that this critic went far beyond acceptable behaviour with sentences such as 'It has already been some time since the people under Heaven started to regard Your Majesty as unworthy.202 Hai Rui was sentenced to death, but released after the emperor died a year later. Another famous example is Huang Zongxi (d. 1695). To counterbalance the politics of the ruler and to encourage new generations of critical literati, he pleaded in his Mingyi daifang lu for universal public education with a curriculum not dictated by the court. ${ }^{203}$

While the Chinese literati seem to have been the most outspoken in their criticism of the ruler, similar forms of dissent are found in the advice texts of other literary traditions. Especially the mirror-for-princes texts in both the European and the Islamic worlds often functioned as a vehicle for (veiled) criticism of the ruling monarchs. ${ }^{204}$ This was done, for example, by criticizing the ruler's advisors or courtiers instead of the ruler himself, by praising the good habits of his predecessors instead of the present ruler, or by comparing the ruler to classical and biblical examples. ${ }^{205}$

\subsubsection{Pen and Sword}

The people of the pen reflected in a wide variety of ways upon their relationship with the people of the sword. In the Arabic literary traditions, the penman's main antagonist is generally the man of the sword. The contrasting images of both groups in the Arabic tradition have come down to us in numerous texts from different genres, from chronicles to poetry. The various arguments are most clearly formulated in so-called literary debates, treatises in which rep-

202 Translation by Ray Huang, 1587: A Year of No Significance (New Haven, 1981) 130-155. See also Pines, Everlasting, 97-100. On Shizong's relationship with his grand secretaries, see John W. Dardess, Four Seasons. A Ming Emperor and His Grand Secretaries in SixteenthCentury China (Lanham and London, 2016).

203 Wm Theodore de Bary, 'Introduction', in: Waiting for the Dawn. A Plan for the Prince (New York, 1993) 30-35.

204 See, for example, Frank Tang, 'Royal Misdemeanour: Princely Virtues and Criticism of the Ruler in Medieval Castile (Juan Gil de Zamora and Alvaro Pelayo)', in: Istvan P. Bejczy and Cary J. Nederman, eds., Princely Virtues in the Middle Ages: 1200-1500 (Turnhout, 2007) 99121; Patricia Crone, God's Rule: Government and Islam (New York, 2004) 315-331.

205 Judith Ferster, Fictions of Advice. The Literature and Politics of Counsel in Late Medieval England (Philadelphia, 1996). 
resentatives of pen (qalam) and sword (sayf) state the various advantages of their position and status, indulge in self-glorification, exhibit their knowledge, and proclaim their superiority over the other. Some of these debates are incorporated in larger collections of advice texts of various kinds. ${ }^{206}$ In accordance with their proclaimed, distinct tasks and roles in society, the people of the pen and the people of the sword are presented with contrasting characters. The people of the pen were, for example, supposed to be eloquent and civilized, while courageous behaviour belonged to the domain of the military. ${ }^{207}$ Generally, these debates end to the disadvantage of the sword. This should not surprise us since the texts were written by the people of the pen. ${ }^{208}$

What is striking, however, is that some fourteenth-century and later debates no longer present an outright winner. ${ }^{209}$ The poet and chancery-secretary Ibn Nubata (d. 1366), for example, refers in his Risala fi-l-Sayf wa-l-Qalam ('Treatise on the Sword and the Pen') to Qur'anic verses that praise pen and sword equally. After mentioning verses from the Surat al-Qalam (Pen) which have been quoted above, ${ }^{210}$ the sword responds with a quotation from the Surat alHadid (Iron) saying 'and we sent down iron in which is material for mighty war, as well as many benefits for mankind'. ${ }^{211} \mathrm{~A}$ few decades later al-Qalqashandi, who also wrote a debate about pen and sword and included it in his Subh

206 See, Adrian Gully, 'The Sword and the Pen in the Pre-Modern Arabic Heritage: A Literary Representation of an Important Historical Relationship', in: Sebastian Günther, ed., Ideas, Images and Methods of Portrayal. Insights into Classical Arabic Literature and Islam (Leiden, 2005) 404.

207 Possibly, another promising analytical tool in this regard might be looking at the penmen's self-definition vis-à-vis the swordsmen from a gender perspective and thus analysing (self-) definitions of manliness. In some of the Arabic narratives people of the pen present themselves as cowards juxtaposing the heroic behaviour of soldiers to clearly demarcate both fields of government. Even if other societies show no such persistent distinction between pen and sword, definitions of manliness still might engender new views.

208 For an outline of the antithesis between pen and sword and a general introduction into the genre of the literary debate, see Geert Jan van Gelder, 'The Conceit of Pen and Sword: On an Arabic Literary Debate', Journal of Semitic Studies 32, no. 2 (1987) 329-36o; Gully, 'The Sword and the Pen', 403-430; Ewald Wagner, 'Die arabische Rangstreitdichtung und ihre Einordnung in die allgemeine Literaturgeschichte', Abhandlungen der Akademie der Wissenschaften und der Literatur in Mainz, geistes- und sozialwissenschaftlichen Klasse, Jhrg. 1962, nr. 8, 435-476 (1962).

209 The authors of these texts knew one another. Gully, 'The Sword and the Pen', 403-407.

210 See 'Specialized Training' p. 427 above.

211 Verse 25 . 
al-Asha, concluded his debate with a conciliation of peace between the two antagonists. ${ }^{212}$

Another variation on the relationship between pen and sword is given by the fourteenth-century North African historian and official Ibn Khaldun (d. 1406). In his Muqaddima, the first book of his Universal History (Kitab al-Tbar), in which he clearly builds on earlier normative presentations of the ideal official, ${ }^{213}$ he does not give general prominence to either pen or sword, but instead argues for a varied picture in which pen and sword take leading roles in turn in specific phases of dynastic history:

It should be known that both the sword and the pen are instruments for the ruler to use in his affairs. However, at the beginning of the dynasty, so long as its people are occupied in establishing power, the need for the sword is greater than that for the pen. In that situation, the pen is merely a servant and agent of the ruler's authority, whereas the sword contributes active assistance.

The same is the case at the end of the dynasty when its group feeling weakens, as we have mentioned, and its people decrease in number under the influence of senility, as we have stated before. The dynasty then needs the support of the military ...

In mid-term of the dynasty, the ruler can to some degree dispense with the sword. His power is firmly established. His only remaining desire is to obtain the fruits of royal authority, such as collecting taxes, holding (property), excelling other dynasties, and enforcing the law. The pen is helpful for (all) that. Therefore, the need for using it increases. The swords stay unused in their scabbards ...214

In short, the antagonism between pen and sword was not static, and it is perhaps not surprising that under the military regime of the Mamluks there is room for a more positive view of the sword. The Mamluk administration saw an increasing influence of people of the sword in administrative positions, such as the ustadar, one of the senior Mamluk emirs, who was responsible for the court's expenses, and the dawadar, the bearer and keeper of the royal

\footnotetext{
212 Al-Qalqashandi, Subh al-a sha, XIV. See also Gully, 'The Sword and the Pen', 410.

213 Maaike van Berkel, 'Ibn Khaldūn, A Critical Historian at Work. The Muqaddima on Secretaries and Secretarial Writing', in: Arnoud Vrolijk and Jan Hogendijk, eds., O ye Gentlemen:Arabic Studies on Science and Literary Culture. In Honour of Remke Kruk (Leiden and Boston, 2007) 247-261.

214 Translation by Rosenthal, Muqaddimah, II, 46-47.
} 
inkwell, who became one of the most important offices in the realm in the late fourteenth-early fifteenth century. 215

In Mughal India the munshi Chandar Bhan 'Brahman' also explicitly refers to the pen and sword as two pillars of the empire in his Chahar Chaman (The Four Gardens'), a text that functioned as a kind of mirror for munshis. ${ }^{216}$ Unlike many of the earlier Arabic authors and more in line with some of the Mamluk writers, Chandar Bhan does not seem to promote one over the other. ${ }^{217}$ On the contrary, he calls for expertise in both fields. While looking back, for example, at the great officials of Akbar's reign (r. 1556-1605) he praises the illustrious minister (wazir) Raja Todar Mal, who had received the title of 'Master of the Sword and the Pen' (sahib al-saif va al-qalam). ${ }^{218}$

Chinese history also has a long tradition in referring to the two pillars of government, wen (civil) and wu (military). The dichotomy was already formulated during the Warring States' period or earlier. Also in China generally, but not exclusively, the literati, the wen people, produced the texts discussing these concepts. The literary presentation of the relationship between the two concepts varied throughout the ages and between authors within the same period. So do the actual social relations between the two groups in society. The general tendency since the late Tang period was, however, towards a greater divide between pen and sword. Although some elite families still produced candidates for both $w u$ and wen positions, separate career paths became the norm. The institutional innovations in the shape of hereditary, registered occupational households during the Yuan period further ensured a separation of civil and military elites. ${ }^{219}$ Nevertheless, the early-Ming emperors still seem to have valued martial capacities and scribal qualities alike. The first Ming emperor, Zhu Yuanzhang (r. 1368-1398) was said to have valued both wu and wen in a way very similar to Ibn Khaldun's position. By referring to antiquity Zhu Yuanzhang saw clear roles for both groups in society, avoiding giving prominence to either one of them:

215 See also Martel-Thoumian, Les civils et l'administration.

216 Rajeev Kumar Kinra, 'Secretary-Poets in Mughal India and the Ethos of the Persian: The Case of Chandar Bhān Brahman' (PhD dissertation, Chicago, 2008) 203.

217 See Kinra, 'Secretary-Poets', 259-26o, 468, 476.

218 Translation by Kinra, 'Secretary-Poets', 187; see also 203 and 259. See also Jos Gommans, Mughal Warfare. Indian Frontiers and Highroads to Empire, 1500-1700 (London and New York, 2002) 94 .

219 I would like to thank Barend Noordam for this information. 
I have heard that in high antiquity when they established their rule the [three] emperors and [five] kings used the military to pacify the world. When it came to preserve their accomplishments, they spoke of the military to spread awe throughout the world. Putting into effect government principles and policies, however, depends on civilian officials. Of these two one must not favour one over the other ... Accordingly, I wish to emulate the institutions of antiquity by establishing two systems of selection for military and civilian affairs and thereby broadly search for worthies in the world [to serve me]..$^{220}$

Indeed, during the early-Ming period the sword seems to have been dominant, while the mid-Ming period (1450-1550) saw a decline in the status of the people of the sword, an increasing influence of the literati at the court, and the culmination of the divide between pen and sword. ${ }^{221}$ The literati of this period often downplayed the role of the military in their texts and as such were responsible for the biased picture of the Ming military and the relationship between $w u$ and wen in modern studies. 222

Under the late-Ming emperors, especially during the reign of Wanli (15721620), the people of the sword were able to recover their prestige thanks to the emperors' interest in the martial and their endeavours to counterbalance the power of the civil officials. ${ }^{223}$ More important for our analysis of the selfperceptions of officials is, however, the cultural intermingling between people of the pen and the military that we can observe in this period. This resulted in self-definitions that used each other's cultural vocabulary. 24 Military men participated in the culture associated with the literati, such as poetry, writing, painting, and calligraphy. ${ }^{25}$ Moreover, men such as the famous general Qi

220 Translation by Elman, Cultural History, 72.

221 See John W. Dardess, Ming China, 1368-1644. A Concise History of a Resilient Empire (Lanham, 2011); David Robinson, Martial Spectacles of the Ming Court (Harvard, 2013).

222 Robinson, 'The Ming Court', 44-45. See also Nicola Di Cosmo, 'Introduction', in: Nicola Di Cosmo, ed., Military Culture in Imperial China (Cambridge Mass. and London, 20o9) 2, who refers to recent developments in the historiography as an 'antimilitarist turn'.

223 Kenneth M. Swope, 'Bestowing the Double-edged Sword: Wanli as Supreme Military Commander', in: David Robinson, ed., Culture, Courtiers and Competition. The Ming Court (1368-1644) (Cambridge Mass. and London, 2008) 61-115.

224 I would like to thank Barend Noordam for his information on the changing relationships between pen and sword in this period. See also Kathleen Ryor, 'Wen and Wu in Elite Cultural Practices during the Late Ming', in: David Robinson, Culture, Courtiers and Competition. The Ming Court (1368-1644) (Cambridge Mass. and London, 2008) 219-242.

225 Ryor, 'Wen and Wu', 220. 
Jiguang (d. 1588) became inspired by Neo-Confucianism in general, and by the influential Ming official and philosopher Wang Yangming (d.1529) in particular, and started to produce texts in which he expressed typical neo-Confucian thoughts, such as the yearning for the suppression of desires and the obedience to the mind-heart. ${ }^{226}$ His son characterized his father in the preface to his biography as follows:

In order to cut the too high costs, which were uncongenial at the time, he returned to the Guards unit that had existed for a long time. His filial piety [to his family] became his loyalty [to the dynasty]; he did not manage his family members and their livelihoods and he happily engaged himself in the Classics. He was especially good at poetry and writing classical Chinese prose; he was an indirect follower of Yangming, ${ }^{227}$ he greatly expounded innate knowing of the good and in his heart he was transparently clear to the point of being pure and chaste. He took command of the refined and the vulgar having a Confucian's spirit and appearance. ${ }^{228}$

Similarly, literati, especially from areas that suffered frequent raids such as the Jiangsu, Zhejiang, and Fujian coasts and the northern frontiers, started to emphasize the importance of both pen and sword. Moreover, in their texts they indicated the problems that had arisen due to the preference of the pen and the downgrading of the sword. The official Xu Xuemo (second half of the sixteenth century), for example, phrased it as follows:

When I was a vice commissioner for military affairs in Xiangyang, some officials of the prefectural administration were not willing to be in the company of the guard commander to pay their respects to the higher provincial authorities ... I said, 'As in the way of Heaven, there is a yang and a yin, so in the court there are civilian and military officials. Why should one insult the other?'229

In the European tradition, the relationship between pen and sword was rather different. Both groups were often less clearly distinguishable in the sources. In

\footnotetext{
226 On the concept of the 'heart-mind' see Rodney L. Taylor and Howard Y.F. Choy, The Illustrated Encyclopedia of Confucianism, 2 volumes (New York, 2005) 236-237.

227 Which means that he did not learn directly from the Master himself.

228 Zuoguo Qi, Qi Shaobao nianpu, Yangwen Gao and Qi Tao, eds. (Beijing, 2003) 1-2. For the translation and reference to this quote I would like to thank Barend Noordam.

229 Translation by Ryor, 'Wen and Wu', 221.
} 
the beginning of our period the people of the pen, often clerics, did not clearly identify as state officials and neither did they position themselves vis-à-vis the other pillar of state administration, those handling the sword. ${ }^{230}$ However, in the course of the sixteenth century a more evident and distinguishable selfimage arose among the people of the pen and clearer traces of the divide between robe and sword became apparent. ${ }^{231}$ The quote from a text by Robert Dallington, Norfolk schoolmaster in the late sixteenth and early seventeenth centuries, shows interesting parallels with the polemics written in the Chinese and the Islamic territories:

And sure if there be difference in Nobilitie, as there must needes bee, because the causes bee different; for some are ennobled by their valour and Martiall knowledge, and others by their Offices and prudence in the manage of matters of Estate: I see no reason, but that these last should be holden the more noble Nobilitie, if I may so say: alwayes giving the first to them that are of Noble houses by Race. ${ }^{232}$

This growing self-awareness of the pen vis-à-vis the sword can be linked to the growing influence of 'robe' officials in the social reality of European polities. However, the nobility continued to identify with the traditional values of the sword, despite the incorporation of penmen among their ranks.

\section{Conclusion}

Self-conscious groups of state officials propagating an occupational ethos and defining the group's role in the political arena can be found in all three regions of this analysis in the period 1300-16oo. The Chinese late-Yuan and early-Ming literatus Wei Su (d. 1372), the Mamluk chancery scribe al-Qalqashandi (d. 1418), and the Neapolitan jurist and high official Lucas de Penna (d. 1390) all wrote

230 See also Hamish Scott, Forming Aristocracy: The Reconfiguration of Europe's Nobilities c. $1300-1750$ (forth coming).

231 For epée-robe clashes in different situations and phases in France, see J.H.M. Salmon, 'Storm over the Noblesse', Journal of Modern History 53, no. 2 (1981) 242-257. For earlier examples perhaps: Autrand, who argues that the members of the Parlement claimed a self-confident robe-ideal. Autrand, Naissance, 245-261 and 263-267.

232 Robert Dallington, The View of France, W.P. Barrett, ed. (London, 1936 [1604]). Quoted from Salmon, 'Storm', 242. 
about the role of the pen in their polities and the indispensable expertise needed for this job.

While the position and status of the people of the pen were debated throughout Eurasia in the period 1300-1600, the detailed comparisons within this chapter have demonstrated that the emergence and growth of self-awareness among these groups followed different paths. The various forms of bureaucratic self-identification have been determined, firstly, by the rhythms of administrative institutionalization, which sparked the emergence of extensive administrative apparatuses. Secondly, the use of written records and the presence of older scribal traditions have been pivotal in the crystallization of bureaucratic identities. And lastly, the interaction of the various power groups at court, and the ways in which the people of the pen identified with each of them, have shaped their self-images.

Chinese literati cultivated a scribal curriculum and self-confident ethos from the Warring States (453-221 BCE) onwards, which reached maturity under the Han dynasty going hand in hand with growing centralization, the introduction of state examinations for officials, and the incorporation of Confucian teaching into their education. Curriculum and ethos were not static- they kept on changing throughout the centuries-but nevertheless the Chinese literati of the Yuan and Ming dynasties could and mostly did refer to these long-standing practices and ideals. Under the Ming, the civil examinations became the decisive recruitment mechanism. Neo-Confucianism was elevated to an empirewide ideology for officials.

The counterparts of the Chinese literati in the Islamic world started to formulate their codes of conduct in Arabic treatises in the course of the eighth century. An important stepping stone for state formation was the development of a set of relatively uniform and centralized bureaucratic practices under the Umayyads. However, the codes of conduct reached maturity under the Abbasids with the expansion of the administration, the introduction and growing use of paper, and the development of a culture that valued writing highly and put trust in written documentation. The Umayyad and Abbasid scribes did not need to develop bureaucratic practices and ideals from scratch, but could build on previous Persian and Byzantine scribal cultures. Many of the early scribes of the Arabic-Islamic caliphate came from scribal families who also had served the Byzantines or Sassanian rulers. In their turn, later officials whether employed by the Mamluks, the Ottomans, or the Mughals referred to their Arabic predecessors and drew from these bureaucratic traditions.

In most polities of post-Roman Europe a substantial and self-aware group of state officials propagating a scribal culture in manuals and treatises did not emerge until the later Middle Ages, with differences in timespan between 
England - among the pioneers - and the German Empire-among the latecomers. A clearly defined group ethos started to develop in the later Middle Ages in Europe with growing state formation, which went hand in hand with the rise of a new, specialized elite staffing the institutions of these polities and the increase of written records in these institutions. Moreover, in Europe social constellations differed from those in the Chinese and Islamic worlds. In early and high medieval Europe scribes had been mostly clerics whose religious, political, or familial, rather than their occupational, identity and affiliations had prevailed. In the course of the period 1300-160o, laymen entered the administrations, but even then religious or noble identities remained dominant, and newcomers aspired to become part of the socially superior nobility instead of defining a separate occupational ideology. However, from then onwards, European officials did start to refer to their own classical, often Roman, legal, epistolary, and rhetorical traditions in instruction texts. ${ }^{233}$

Throughout Eurasia the gradual development from a patrimonial to a more meritocratic officialdom seems to have been pivotal in the ideal presentation of a self-conscious identity among officials. Some of the most detailed and recurring themes in the self-presentations of the people of the pen are those describing the training, expertise, and erudition of the group. It was not their pedigree, but their learnedness - achieved through superior education and specialized training - that, in their self-perceptions, distinguished them from the other groups in society and which they advertised in their self-representations to legitimize their position.

Yet, while self-presentations emphasize the meritocratic prerequisites of the job, social reality was more nuanced. The investment in the years of study needed to pass the civil examinations in the Chinese territories often were out of reach for members of artisan and farmer families. For their selection, entry level, and professional success, officials of the Islamic administrations remained highly dependent upon informal and personal networks. Similarly,

233 For similar conclusions on the diverging trajectories of the various Eurasian worlds, see Patrick J. Geary, Daud Ali, Paul S. Atkins, Michael Cooperson, Rita Costa Gomes, Paul Dutton, Gert Melville, Claudia Rapp, Karl-Heinz Spieß, Stephen West and Pauline Yu, 'Courtly Cultures: Western Europe, Byzantium, the Islamic World, India, China, and Japan', in: Benjamin Z. Kedar and Merry E. Wiesner-Hanks, The Cambridge World History, Volume 5: Expanding Webs of Exchange and Conflict, 500 CE-1500CE (Cambridge, 2015) 179-205. Unfortunately, I was unable to check the following, relevant publication, which appeared after I finished this chapter: Peter Crooks, Empires and Bureaucracy in World History. From Late Antiquity to the Twentieth Century (Cambridge, 2016). 
the highest positions in the European administrations could only be reached with the right connections.

In all three regions officials produced self-images in texts that can be classified under the generic term of advice (or mirror) literature. Numerous variations exist, stylistically and thematically, not only between the three regions of this analysis, but also within each of the regions, from author to author and genre to genre. Advice texts by and for state officials proved to be more numerous in the Islamic and Chinese traditions in the period 1300-16oo, but were also present in Europe.

Through the comparative approach of this chapter conspicuous differences between the three regions in the position of the authors of these texts and their place within the administration have become apparent. In Europe, most self-images were produced by the top judicial administrators of the emerging polities, some of them clerics. Instruction texts for financial and chancery officials are more pragmatic and contain fewer obvious identity markers. In the Chinese territories officials of various ranks wrote on the identity of the group and collected important texts by famous predecessors. Their culture and ideology were directly related to a broader group of people who had passed the civil examinations, but did not work as state officials. In the Islamic world, the officials propagating a group ethos mostly belonged to the group of the epistolary scribes staffing the chanceries.

The detailed comparative analysis of the self-perceptions of officials enabled me to demonstrate a few remarkable parallels in the themes discussed in advice texts by officials throughout the three main worlds of our book. The emphasis on education and expertise has already been mentioned. More in particular, a threefold division into general cultural literacy; specialized training in, for example, calligraphy, law, accounting, or epistolary traditions; and moral upbringing is apparent. Notable variations exist in the presentation of the capacities of various specialized groups of officials. The Chinese literati disdainfully cast aside lesser functionaries, clerks, runners, and notaries, while Arabic chancery scribes do the same with their financial colleagues. Obviously, what is presented in the advice literature is an ideal self-image, a norm. In everyday life, these ideals were often far from being achieved. Embezzlement, nepotism, neglect, ignorance, lack of collegiality, malice, and sloppiness were common in all administrations. What these texts do show, however, is that officials developed clear ideas on what good and bad governance should be and how as a group they should contribute to it.

While self-representations on training and ethics show obvious parallels throughout Eurasia, the portrayal of social relations has, at first sight, more variations. All three traditions emphasize a kind of natural hierarchy and con- 
nectedness between ruler and official, using metaphors such as the head and arms of a human body or the various rivers and streams flowing to the ocean. However, Chinese literati seem much more explicit and self-confident in their criticism of the ruler than their counterparts in the Islamic and European worlds. Although in everyday life many Chinese literati also complied, afraid of jeopardizing their hard-won position, it remained part of their Confucian ideals to keep a critical attitude towards the ruler and act as his guide. Dissidence and criticism are not absent in European and Islamic mirrors, but presented in codes and through veiled arguments by, for example, praising 'good' predecessors or criticizing the 'bad' advisors of the ruler.

Variations across Eurasia are also discernible in the way in which officials portray the relationship between pen and sword. The Islamic and Chinese worlds have a long tradition of contrasting pen and sword in their literary culture. Such a dichotomy is less prominent in the self-presentations of European officials, although from the sixteenth century onwards the competition between robe and épée became a recurring theme in polemical texts. In analysing the relationship between pen and sword, ideal presentations and literary polemics are again often quite far removed from social realities. In everyday life many forms of cooperation and overlap between the worlds of pen and sword existed. Ibn Khaldun argued that pen and sword often alternated in their positions: the sword was prominent during regime changes and the pen in times of consolidation. In sixteenth-century Ming China the military elite identified with the pen culture of the literati. A few striking variations in pen-sword relations between our three major regions have become apparent. In Europe the dominant upper echelon of nobles still cultivated its traditional connections with battlefield glory, although in the course of the centuries it had incorporated many men risen in government office. For the Chinese territories in the Song-Yuan-Ming era wen seems to have been on top despite shorter periods of $w u$ dominance. ${ }^{234}$ In the Islamic world the picture is more diffuse. The pen was the culturally dominant group and often epitomized the ideal, but in social reality the sword generally took the lead and dominated politics.

By positioning themselves vis-à-vis other groups in society and by defining their own qualities and expertise, officials claimed an indispensable role in the imperial enterprise. They legitimized their position by emphasizing time and again that only those who were well-trained and refined could access official-

234 Recent authors such as David Robinson have emphasized the necessity to qualify and revise the biased and harmonized image of court politics produced by literati, but they do not question the social and cultural prominence of wen culture. 
dom. Their role was one of intermediary between ruler and subject, eloquently communicating the ruler's decrees to his subjects, morally defending good governance and correcting individuals whenever necessary. Officials saw themselves as the ears through which the ruler heard, the eyes through which he saw, and the tongue through which he spoke.

Obviously, social reality was less one-dimensional and smooth. The exalted ideals on expertise, erudition, and just rule were hard to meet, in the first place for officials themselves, but also for the rulers they served. Many were tempted to feather their own nest. And even highly erudite, well-trained, and just officials who had passed every possible examination remained dependent on the whims of the ruler and the competition for access to him with, for example, eunuchs, court women, and the people of the sword. However able they may have been, they were never sure of their position. Generally, they had to gain or secure their status by compromising their high ideals and complying with their superiors' wishes. Through their pen they had reached a good position and through their pen they earned a living and could secure their reputation for the future. As the Mamluk scribe al-Qalqashandi explained while deliberating on his own position: it might not be ideal, but working as an official was the best possible option for someone like him, someone with the mind of a scholar. Al-Qalqashandi sketches a compelling picture of the people of the pen: not only have they been successful in directing our visions of officialdom, but on an even wider scale, as scholars and writers, they channelled, and continue to determine, our views on the history of their polities and are thus, posthumously, also holding the historians' pens. 